Kościót Chrystusowy, red. T. Dzidek, Ł. Kamykowski, A. Napiórkowski, Kraków 2019, s. 73-137 (Teologia Fundamentalna, 4) DOI: http://dx.doi.org/10.15633/9788374388368.05

\title{
IV. Znaki prawdziwości Kościoła
}

ks. Józef Morawa

Prezentowana powyżej historyczno-teologiczna analiza ustanowienia przez Jezusa Chrystusa swojego Kościoła kieruje się w stronę podania kryteriów rozpoznawania jego prawdziwości, które zawarte są w pytaniu: dzięki jakim znakom można stwierdzić, że wspólnota wierzących w danym okresie dziejów, nazywana Kościołem Jezusa Chrystusa, Jego Ciałem, Oblubienicą, Budowlą Bożą, Winnicą czy Owczarnią Chrystusa, Wspólnotą, jest rzeczywiście tożsama z wizją i wolą Jego Założyciela? Postawione tutaj zagadnienie pojawiało się nieustannie w całej historii Kościoła i obecnie należy do najważniejszych dla uzasadnienia jego tożsamości i identyczności.

\section{A. Odkrywanie znamion Kościoła w jego dziejach}

Już pierwsi wyznawcy Jezusa Chrystusa zastanawiali się nad tym, co czyni ich wspólnotę prawdziwym Kościołem Boga, jakie są kryteria, względnie znamiona, prawdziwego Kościoła, przy pomocy których można by go przedstawić światu, jak też co decyduje o prawdziwym w nim członkostwie, zwłaszcza chrześcijan pochodzenia pogańskiego ${ }^{1}$. Dowodem tych poszukiwań były decyzje tzw. soboru apostolskiego w Jerozolimie (por. Dz 15). Ich treść, a także podejmowana próba wyjaśnienia stosunków Kościoła z Izraelem i obrona przeciw gnostycyzmowi przyniosły stwierdzenia, które w świadectwie Nowego Testamentu mówią o Kościele zbudowanym na fundamencie apostołów i proroków, z Jezusem

1 Por. W. Kasper, Die Kirche als Mysterium. Was glaubt die Kirche von sich selbst, [w:] M. Seybold (red.), Fragen in der Kirche und an die Kirche, Eichstätt-Wien 1988, s. 32-77; H. Seweryniak, Święty Kościót powszedni, Warszawa 1996, s. 43nn. 183nn. 
Chrystusem jako podstawą i głową (por. Ef 2, 20; Kol 1, 18) ${ }^{2}$. W dwutysiącletnich dziejach Kościoła sposób określenia jego prawdziwości przechodził trzy zasadnicze fazy ${ }^{3}$.

1. W czasach poapostolskich znanych było prawie sto cech, zwanych też znamionami Kościoła (notae Ecclesiae), spośród których najczęściej wymieniano cztery. Weszły one do Symbolu Konstantynopolitańskiego (381 r.) w brzmieniu: „wierzę w... jeden, święty, powszechny i apostolski Kościół” ${ }^{4}$. Cechy te, przyjęte powszechnie przez prawie wszystkich chrześcijan, określały istotę prawdziwego Kościoła założonego przez Jezusa Chrystusa ${ }^{5}$.

2. Pytania o Kościól w następnych stuleciach nasiliły się na skutek ruchów katarów, waldensów, albigensów i husytów. Swój szczyt osiągnęły w postulatach reformacji w XVI w., która istotę i prawdę swojej nauki o Kościele interpretowała odmiennie i równocześnie mogła legitymować się członkami przelewającymi męczeńską krew za przyznawanie się do własnej konfesji we wzajemnych religijnych walkach.

W podejmowanych przez reformatorów dysputach eklezjologicznych tego czasu znamiona Kościoła, choć występowały w ich Credo, nie odegrały większej roli. Marcin Luter uważał je za cechy ukrytego Kościoła, które należało uzupełnić o notae externae Kościoła widzialnego ${ }^{6}$. Kryterium prawdziwości Kościoła jest według niego prawidłowe głoszenie Ewangelii i właściwe sprawowanie sakramentów ${ }^{7}$.

Po katolickiej stronie od XVI wieku uwidoczniło się to w prezentowaniu w apologetycznej formie demonstratio catholica, w której właśnie wymienione w Credo znamiona Kościoła stanowiły jedną z najważniejszych form argumentacji

${ }^{2}$ H. I. Marrou, Od prześladowań za Dioklecjana do śmierci Grzegorza Wielkiego (303-604), [w:] J. Daniélou, H. I. Marrou Historia Kościota, t. 1: Od początków do roku 600, Warszawa 1984, s. 235.

3 Por. H. J. Pottmeyer, Die Frage nach der wahren Kirche, [w:] HFTh, s. 212-214.

${ }^{4}$ Por. Sobór Konstantynopolitański I, Symbol, [w:] BF, IX, 10; KK 8.

5 Por. HFTh, t. 3, s. 13; por. H. J. Pottmeyer, Die Frage nach der wahren Kirche, [w:] HFTh, t. 3, s. $212 \mathrm{nn}$. W prezentowanym okresie, tj. w szeroko pojmowanym pierwszym tysiącleciu spotyka się świadectwa omawiania pojedynczych znamion, w zależności od uwypuklanych problemów w Kościele. I tak Ireneusz czy Cyprian w sporach z gnostykami i heretykami powoływali się na apostolską sukcesję i prawowitość biskupów, Augustyn na katolickość, a Wincenty z Lerynu na uniwersalność i starożytność, por. także: Y. Congar, Die Wesenseigenschaften der Kirche, [w:] W. Beinert, Y. Congar i inni (red.), Mysterium Salutis, t. IV/1: Das Heilsgeschehen in der Gemeinde, Einsiedeln-Zürich-Köln 1972, s. 359.

${ }^{6}$ Por. W. Kasper, Kościót katolicki. Istota, rzeczywistośc, postannictwo, Wydawnictwo WAM Kraków 2014, s.273.

7 Por. A. Napiórkowski, Herezje, [w:] LTF, s. 456-462. 
antyreformatorskiej. Demonstratio catholica swoje apogeum osiągnęło w nauce Vaticanum I o prymacie papieskim (via primatus) i u Piusa XII w encyklice Mystici Corporis Christi. Dominantą tej nauki było stwierdzenie, że jedynym i prawdziwym Kościołem Jezusa Chrystusa jest Kościół rzymskokatolicki (nota romanitatis): „sola Ecclesia Romana est vera Ecclesia Christi” (tylko Kościól Rzymski jest prawdziwym Kościołem Chrystusa). Trzonem nauki Piusa XII było ujęcie Kościoła jako Mistycznego Ciała Chrystusa.

3. Nauka Vaticanum II faktycznie zakończyła jednostronną apologetykę katolicką i po raz pierwszy w długiej, bo dwa tysiące lat trwającej, historii Kościoła podjęła próbę odpowiedzi na najistotniejsze pytania dotyczące jego istoty i posłania. Sobór Watykański II (1962-1965), którego wiodącym tematem było adagium: Ecclesia ad intra i Ecclesia ad extra, podją po raz pierwszy w historii soborów tak wyraźnie postawione pytania: Kościele, kim jesteś? Kościele, co mówisz sam o sobie? W swojej nauce Ojcowie soborowi nawiązali do starożytnej formuły wyznania chrześcijańskiego o czterech znamionach Kościoła Chrystusowego, przez co podkreślili ich niezbywalną aktualność. Równocześnie odeszli od identyfikowania Kościoła Jezusa Chrystusa z Kościołem rzymsko-katolickim (zamiast: „Kościół Chrystusowy jest [est] Kościołem rzymskokatolickim”, Vaticanum II stwierdza: „Kościół Chrystusowy trwa [subsistit] w Kościele katolickim”), jak też uznali eklezjalne elementy (vestigia ecclesiae) w innych Kościołach i wspólnotach chrześcijańskich. Przez takie sformułowanie przyznali pośrednio, że i w Kościołach niekatolickich należy dowartościować treści znamion przypisywanych dotąd sobie w całości. Otwarło to nową możliwość ekumenicznego poszukiwania odpowiedzi na pytania dotyczace faktycznych, od Boga pochodzących, znaków jego prawdziwości, a opartych na przypomnieniu fundamentalnych zapisów biblijnych ${ }^{9}$.

Rozważanie problemu widzialnej jedności Kościoła w ramach ruchu ekumenicznego jest nierozdzielnie związane z pierwszym jego znamieniem, jednościq (jeżeli sięga się do niego, z konieczności należy postawić zagadnienie znaczenia trzech pozostałych). Po wtóre, wszystkie cztery znamiona Kościoła należą do istoty wyznania wiary pierwotnego Kościoła, które jest coraz częściej postrzegane jako fundament wszystkich Kościołów chrześcijańskich. W końcu, używanie znamion, które szczególnie cenili sobie reformatorzy, jak wspomniana wyżej tzw. „czysta i prawdziwa Ewangelia” i „właściwe szafarstwo sakramentów”, jest obecnie także u protestantów oceniane krytycznie ${ }^{10}$.

8 KK 8.

9 Por. J. Ratzinger, Tajemnica Jezusa Chrystusa, Kielce 1994, s. 69-70.

10 Por. tamże, s. 231n; S. Rosa, Teologia fundamentalna, t. 2: Eklezjologia, Tarnów 2000, s. 163. 


\section{Znamiona a wiara w Kościół}

W nicejsko-konstantynopolitańskim wyznaniu wiary tekst odnoszący się do Kościoła został umieszczony w części poświęconej Duchowi Świętemu: Wierzę w Ducha Świętego... jeden, święty, powszechny i apostolski Kościót. Wyjaśnienie treści tego artykułu wiary jest więc poniekąd obowiązkowe w każdym opracowaniu teologicznym, pastoralnym i liturgicznym ${ }^{11}$. Katechizm Kosciota Katolickiego mówi o tym następująco:

Wiara, że Kościół jest „święty” $i$ „powszechny” (katolicki) oraz że jest „jeden” $i$,apostolski” [...], jest nieodłączna od wiary w Boga Ojca, Syna i Ducha Świętego. W Symbolu Apostolskim wyznajemy wiarę w święty Kościół (Credo... Ecclesiam), ale składnia łacińska używa tu innej formy, niż w artykule odnoszącym się do wiary w Boga (Credo in Deum), by nie mieszać Boga i Jego dzieł, lecz by wyraźnie przypisać dobroci Bożej wszystkie dary, jakich udzielił swojemu Kościołowi ${ }^{12}$.

\section{Sposób prezentacji znamion}

Pozostaje jeszcze pytanie o sposób prezentacji znamion w wykładzie fundamentalno-teologicznym ${ }^{13}$. Zmiana nazwy $\mathrm{z}$ apologetyki na teologię fundamentalną nie jest tylko sprawą werbalną ${ }^{14}$. $Z$ pewnością ma rację $S$. Pié-Ninot, gdy pisze, że

traktat eklezjologiczny w historii teologii ma nie tyle charakter tekstu, ile kontekstu duchowego, społecznego, liturgicznego, kanonicznego, który ujawnia się właśnie in medio Ecclesiae $^{15}$.

I ten wzgląd stoi u podstaw planu niniejszego przedłożenia treści znamion, które zawiera najpierw charakterystykę dogmatyczną treści danego znamienia,

$11 \mathrm{O}$ miejscu Kościoła w różnych wyznaniach wiary por. BF IX, 1-46, w indeksie rzeczowym, s. 698; DS nr 1-76; H. Seweryniak, Święty Kościót powszedni, Warszawa 1996, s. 183-192.

12 KKK 750. KKK podaje rozległą naukę o znamionach Kościoła w punktach 811-870.

13 Por. S. Pié-Ninot, Wprowadzenie do eklezjologii, Kraków 2002, 73-95; S. Rosa, Teologia fundamentalna, t. 2: Eklezjologia, dz. cyt., s. 161-185; H. Seweryniak, Święty Kościót powszedni, dz. cyt., 193-224; tenże, Świadectwo i sens, Płock 2001, 467-484; Y. Congar, Die Wesenseigenschaften der Kirche, art. cyt., s. 357-594; S. Nagy, Chrystus w Kościele. Zarys eklezjologii fundamentalnej, Wrocław 1982, 257-300.

14 Por. S. Pié-Ninot, Wprowadzenie do eklezjologii, dz. cyt., s. 19-23.

15 Tamże, s. 8. 
następnie rys biblijno-historyczny poruszanej problematyki oraz aktualne do niej odniesienia.

\section{B. Jedność}

Wyrażenie credo unam ecclesiam znajduje się na czele czterech znamion Kościoła w jego wyznaniu wiary. Oznacza najpierw jedyność wspólnoty założonej przez Jezusa Chrystusa, a po wtóre jej wewnętrzną zwartość w zasadniczych elementach wiary, kultu i jedności społeczno-organizacyjnej ${ }^{16}$.

\section{Treść pojęcia}

Znamię jedności Kościoła w swoim wymiarze ontologicznym wskazuje, że jej źródłem, fundamentem i modelem jest trynitarna jedność Boga Ojca i Syna w Duchu Świętym, stanowiąc najwyższą formę w miłości (także jako jedność w wielości). Stąd Kościół jako trynitarne odbicie miłości Boga jest wspólnotą, w której poszczególni członkowie w duchu Chrystusa budują razem nową społeczność wiary, nadziei, miłości, świętowania, modlitwy, cierpienia i działania. Sp rawcą tej jedności jest Jezus Chrystus, który przez swoje dzieło zbawcze pojednał wszystkich ludzi z Bogiem w jednym ludzie i w jednym Ciele, tj. w jednym Kościele ${ }^{17}$. Mocą tej jedności Kościoła jest Duch Święty, zwany też jego duszq, który:

mieszka w wierzących i napełnia cały Kościół oraz nim kieruje, jest sprawcą tej dziwnej wspólnoty wiernych i tak dogłębnie wszystkich zespala w Chrystusie, że jest zasadą jedności Kościoła ${ }^{18}$.

Jedność Kościoła w jego ziemskim pielgrzymowaniu można rozpatrywać na dwóch płaszczyznach. Pierwsza charakteryzuje się napięciem eschatologicznym, mającym swój początek w zbawczym dziele Jezusa Chrystusa i zdążającym ku swemu ostatecznemu wypełnieniu, kiedy to nastanie pełna, doskonała jedność i Bóg będzie wszystkim we wszystkich (1 Kor 15, 28). Jej realizacja naznaczona

${ }^{16}$ Por. Y. Congar, Die Wesenseigenschaften der Kirche, art. cyt., s. 369nn; J. Krasiński, Znamiona Kościota, s. 58n.; S. Rosa, Teologia Fundamentalna, t. 2: Eklezjologia, dz. cyt., s. 165nn.; H. Seweryniak, Święty Kościót powszzedni, dz. cyt., s. 198n.; S. Nagy, Chrystus w Kościele, dz. cyt., s. 257-300; S. Pié-Ninot, Wprowadzenie do eklezjologii, dz. cyt., s. 74nn; por. także: W Kasper, Kościót katolicki, dz. cyt., s.275nn.

${ }_{17}$ Por. KDK 78.

${ }^{18}$ DE 2; por. KKK 813-814. 
jest jednak grzesznością i słabością człowieka, a także narażona na ciągły atak Szatana chcącego wykorzystać niedoskonałą ludzką kondycję do nieustannych podziałów. Kościół już jest jeden w darze i w powołaniu, a jeszcze nie w pełnym ich urzeczywistnieniu, które nastąpi przy wypełnieniu się czasu.

$\mathrm{W}$ wymiarze historiozbarwczym i eschatologicznym ${ }^{19}$ znamię jedności Kościoła dotyka podstawowego problemu człowieka i całej wspólnoty ludzkiej, która jest naznaczona przez moc grzechu i Szatana, co oddziela ją od Boga, dzieli ludzi między sobą i dokonuje zakłócenia wewnątrz osoby ludzkiej. Wszelkie poszukiwania odzyskania jedności bez Boga stają się powodem jeszcze większych podziałów (por. Rdz 11, 1-9) i grożą samozniszczeniem człowieka i jego dzieł. Kościół jawi się tutaj dla człowieka i świata jako znak i środek (sakrament) pojednania człowieka z Bogiem i z innymi ludźmi mocą głoszonej Ewangelii Jezusa Chrystusa i przez podejmowanie służby na rzecz pojednania ludzkości ${ }^{20}$.

Wspomniana wyżej trynitarna miłość (fundament jedności Kościoła) ma swój wymiar widzialny, który konkretyzuje się w wyznawaniu jednej, od apostołów otrzymanej wiary (vinculum symbolicum), celebracji kultu Bożego, zwłaszcza sakramentów (vinculum liturgicum) i sukcesji apostolskiej za pośrednictwem sakramentu święceń, która przez swoją posługę strzeże braterskiej zgody rodziny Bożej (vinculum sociale/communitarium) ${ }^{21}$. Wspomniane trzy vincula mogą być też nazwane środkami do budowania jedności Kościoła.

\section{Refleksja biblijno-historyczna}

Treść znamienia jedności jest zakorzeniona w podstawowej idei stworzenia i odkupienia człowieka, a także całego świata. Jej przybliżenie pomoże w zrozumieniu roli budowania jedności w samym Kościele, a także jego zadania bycia sakramentem wewnętrznego zjednoczenia z Bogiem i wspólnoty całego rodzaju ludzkiego ${ }^{22}$.

\section{A. W STARYM PRZYMIERZU}

Stworzony przez Boga wszechświat jest pierwszym wyraźnym znakiem Jego zamysłu miłości i mądrości. W jego wielkiej i cudownej różnorodności objawia się przedziwna harmonia jedności i celowości, która wzywa do uznania Stwórcy. Ten

19 Aspekt eschatologiczny stanowi punkt wyjścia dla Y. Congara w rozważaniu tematyki jedności Kościoła: Die Wesenseigenschaften der Kirche, art. cyt., s. 368.

20 Por. tamże, s. 814; S. Wiedenhoffer, Ekklesiologie, [w:] Handbuch der Dogmatik, t. 2, dz. cyt., s. 113 .

${ }^{21}$ Por. Dz 2, 42; KK 14; DE 2; KK 14; KPK, kan. 205; J. Morawa, Sukcesja apostolska, [w:] LTF, s. 1141-1147.

22 Por. KK 1. 
świat został dany człowiekowi, aby on, nim władając, doszedł do swej wewnętrznej jedności, co mógł wypełnić tylko wtedy, gdy trwał w łączności z Bogiem, uznając swoją zależność od Niego przez pełną zaufania wierność i jedność z braćmi. Niewierność Bogu zrodziła niepokój człowieka w jego własnym sercu (por. Rdz 1-11; Mdr 13, 1nn; Rz 1, 20nn) oraz spowodowała podziały niszczące jedność małżeńską i braterską, której efektem jest zaprzepaszczona integralność społeczna.

Źródłem tego rozproszenia jest grzech i Szatan, któremu człowiek dał się zwieść. Fakt skłócenia ludzi, czego symbolem jest Wieża Babel (por. Rdz 11, 1-9), potwierdza cała historia ludzka. Gromadzenie na nowo ludzi w jedną rodzinę ma swój historyczny początek w powołaniu Abrahama i w przymierzu Izraela pod Synajem (por. Wj 19n), które, oparte na objawieniu woli Boga w Jego prawie i na przyjęciu go przez wiarę (por. $\mathrm{Oz} 2,22$ ), stało się podstawą odbudowania zerwanej jedności. Wyraźnym przykładem jest działanie sędziów Izraela, królów, a zwłaszcza posłannictwo proroków (por. Lb 27, 16-17; Ez 34, 1-10nn).

\section{B. W DZIAŁALNOŚCI JEZUSA CHRYSTUSA}

Szukanie przez Boga rozproszonych ludzi i ich gromadzenie wypełniło się w dziele Jezusa Chrystusa. W Nim Ojciec niebieski jednoczy wszystkich, którzy Go kochają i w Niego wierzą. On z woli Ojca tworzy ze wszystkich ludów swoje Ciało - Kościół (por. Ef 2, 14-18).

Jezus gromadził wokół siebie słuchaczy ze wszystkich warstw społecznych, wybrał uczniów, a następnie Dwunastu z Piotrem na czele, których przysposabiał do zagarniania w sieci królestwa Bożego czy też zbierania w Bożej owczarni ludów wszystkich czasów. Sam Jezus swoją misję przedstawiał w obrazie dobrego pasterza, który zna swoje owce w ich różnorodności (por. J 10, 14-16). Fundamentalne znaczenie ma Jego śmierć na krzyżu, której celem było zgromadzenie rozproszonych dzieci Bożych w jedno (por. J 11, 51n), na co wskazał sam w słowach: „A ja, gdy zostanę nad ziemię wywyższony, przyciągnę wszystkich do siebie” (J 12, 32). Uczniowie, naśladując Jego służebną posługę pasterską, będą mogli wypełniać zadanie jednoczenia jedynie na wzór Jezusa, który nie przyszedł, aby Mu służono, ale by służyć i dać swoje życie na okup za wielu (por. Mk 10, 42-45; Mt 20, 24-28).

Świadectwem dzieła Pana Jezusa dla gromadzenia ludzi w jedno są ewangeliczne opisy ustanowienia Eucharystii. Wydarzenie z Wieczernika oraz poszczególne jego elementy (zgromadzenie, ustanowienie Nowego Przymierza i nowego kultu) stanowią podstawę dla budowania jedności. Z synoptycznym przekazem wiąże się świadectwo św. Jana, na które składa się treść nowego przykazania miłości pomiędzy samymi uczniami (por. J 13, 34-35; 15, 12-17), zapowiedź umocnienia Duchem Świętym i uroczysta modlitwa Jezusa o jedność dla samych apostołów i dla Kościoła, który ma rozpocząć misję w historii świata i człowieka 
(por. J 17). Charakterystyczną cechą tej modlitwy jest jej trynitarność - źródło wszelkiej jedności Kościoła tkwi w jedności Osób Trójcy Świętej:

A nie tylko za nimi proszę, ale i za tymi, którzy dzięki ich słowu będą wierzyć we mnie; aby wszyscy stanowili jedno, jak Ty, Ojcze, we mnie, a ja w Tobie, aby i oni stanowili jedno w nas, aby świat uwierzył, żeś Ty mnie posłał. I tak chwałę, którą mi dałeś, przekazałem im, aby stanowili jedno, tak jak my jedno stanowimy. Ja w nich, a Ty we mnie! Oby się tak zespolili w jedno, aby świat poznał, żeś Ty mnie posłał i żeś Ty ich umiłował tak, jak mnie umiłowałeś ( $\mathrm{J}$ 17, 20-23).

Po swoim zmartwychwstaniu Jezus znowu zgromadził rozproszonych uczniów wokól siebie i, umocnionych pewnością swego zwycięstwa nad śmiercią, wyposażył w dar niszczenia największej przeszkody jedności, którą nade wszystko jest grzech, przekazując im władzę jego odpuszczania (por. J 20, 21-23). Potwierdził też posługę apostoła Piotra jako powszechnego pasterza nowej owczarni Bożej, którą jest Kościół (por. J 21, 15nn).

\section{W PIERWOTNYM KOŚCIELE}

W opisie życia wspólnoty jerozolimskiej w Dziejach Apostolskich św. Łukasz prezentuje zarys pierwszej eklezjologii, „przy pomocy której chce określić ramy możliwego rozumienia Kościoła w przyszłości”23. Ukazuje ona istotę Kościoła w dynamice jego drogi przez historię, która rozpoczęła się wraz z zesłaniem Ducha Świętego łączącego zebranych we wspólnocie, której z Maryją i apostołami (por. Dz 1, 12-14; 2, 1) w centrum. W Łukaszowym tekście swoje apogeum proces ten znajduje w przejściu Ewangelii od Żydów do pogan, z Jerozolimy do Aten, Koryntu i Rzymu. Tym samym katolickość Kościoła stawała się coraz bardziej widzialna. Równocześnie, pomimo napięć i trudności oraz wzrastającej liczby członków z rozległych obszarów ówczesnego świata, Kościół starał się zachować jedność nie tylko wewnętrzną, ale i zewnętrzną. Wzorem i odniesieniem dla powstających nowych wspólnot chrześcijańskich i Kościołów pozostawał w pierwszym pokoleniu apostolskim Kościół w Jerozolimie, co można wykazać, posługując się tzw. streszczeniami (summariami) z Dziejów Apostolskich.

W pierwszym z nich (por. Dz 2, 42-47) wzorcowym znakiem Kościoła wszystkich wieków jest jedność, którą Autor Dziejów wyraził słowem wspólnota - koinonia. Wyrażała się ona: w trwaniu w nauce apostołów; wspólnych posiłkach; wspólnej modlitwie, na którą udawano się w ściśle określonym czasie; we wspólnocie dóbr materialnych oraz we wspólnym łamaniu chleba, tj. w Eucharystii.

23 J. Ratzinger, Tajemnica Jezusa Chrystusa, dz. cyt., s. 69. 
Jedność ta rozciągała się na cały obszar życia pierwszych chrześcijan i stała się ważnym elementem świadectwa „nowej drogi”, które przyciągało nowych wyznawców. We wspomnieniowym opisie widoczna jest tworząca się trwała struktura Kościoła, oparta na Eucharystii.

Drugie summarium z Dziejów Apostolskich (por. 4, 32-35), zaczynające się od słów: „Jeden duch i jedno serce ożywiały wszystkich wierzących”, podkreśla inny rys jedności społeczności wczesnochrześcijańskiej, jakim była wspólnota dóbr materialnych i uwrażliwienie na potrzeby bliźnich. Jej wynikiem było rozwiązywanie kwestii socjalnych z pożytkiem dla potrzebujących członków gminy. Przyczyniała się też do wzrostu życzliwości ze strony niechrześcijan.

W trzecim summarium (por. 5, 12-16) wskazano, że jedność chrześcijan umożliwiała owocne apostołowanie i świadczenie o Chrystusie.

\section{D. ŚWIADECTWO ŚW. PAWŁA}

Apostoł Narodów podkreśla wielki wysiłek pastoralny i teologiczny skierowany na jednoczenie w Kościele różnorodnych darów oraz wychowywanie wszystkich do coraz owocniejszego współżycia. Kościół Jezusa Chrystusa staje się jedynym miejscem tworzenia się nowej ludzkości, gdzie usunięto wszelkie podziały stanowe, społeczne, ze względu na płeć, rasę czy kulturę.

Św. Paweł daje też podstawę do tworzenia teologicznego opisu fundamentów tej jedności według trzech ściśle ze sobą związanych faktów zbawczych: wiary, sakramentów, pasterzowania. Poniżej zostanie przedstawione krótkie ich omówienie. Jed ność w wierze. W Liście do Efezjan apostoł zachęca do jej realizowania:

A zatem zachęcam was ja, więzień w Panu, abyście postępowali w sposób godny powołania, jakim zostaliście wezwani, z całą pokorą i cichością, z cierpliwością, znosząc siebie nawzajem w miłości. Usiłujcie zachować jedność Ducha dzięki więzi,jaką jest pokój. Jedno jest Ciało i jeden Duch, bo też zostaliście wezwani do jednej nadziei, jaką daje wasze powołanie. Jeden jest Pan, jedna wiara, jeden chrzest. Jeden jest Bóg i Ojciec wszystkich, który [jest i działa] ponad wszystkimi i we wszystkich $(4,1-6)$.

Świadectwo troski o jedność członków Kościoła zawarte jest przykładowo w staraniach o jej przywrócenie pośród Koryntian (por. 1 Kor 1, 10-16; 3, 1-7) czy też w przestrogach posuniętych aż do groźby rzucenia przekleństwa - anathemy na pseudo-apostołów głoszących ,inną Ewangelię”i na wiernych ulegających ich nauce (por. Ga 1, 6-9). Kościół bowiem jest tylko jeden, tak jak i Chrystus (por. 1 Kor 1, 13).

Jedność w sakramentach. W Pierwszym Liście do Koryntian apostoł Paweł wskazuje na Eucharystię jako istotny element jedności: 
Kielich błogosławieństwa, który błogosławimy, czyż nie jest udziałem we Krwi Chrystusa? Chleb, który łamiemy, czyż nie jest udziałem w Ciele Chrystusa? Ponieważ jeden jest chleb, przeto, my, liczni, tworzymy jedno ciało. Wszyscy bowiem bierzemy z tego samego chleba (1 Kor 10, 16-17).

Celebracja Eucharystii oznacza jedność z Chrystusem i tworzy podstawę wspólnoty członków gminy. Łączy ich bowiem jeden i ten sam Chrystus, którego przyjmują, spożywając te same postaci sakramentalne ${ }^{24}$.

Przy omawianiu pouczeń apostolskich dotyczących jedności Kościoła opartej na sakramentach należy koniecznie wspomnieć tekst z Listu do Efezjan 5, 22-32. W swojej bogatej treści eklezjologicznej, moralnej i pastoralnej uwypukla jej fundament, którym jest oblubieńcza miłość Chrystusa do Kościoła. Świadczy o niej wydanie się Chrystusa za Kościół (por. w. 25). Jedność Chrystusa i Kościoła ma z kolei stanowić podstawę wspólnoty małżeńskiej ${ }^{25}$.

Jedność z pasterzami i pasterzy między sobą. Obecność Dwunastu i ich następców (por. Dz 2, 42-47) oraz przekazywana przez nich nauka stanowiły przestrzeń, w której wszyscy trwali we wspólnocie z sobą, w łamaniu chleba (tj. w Eucharystii) i w modlitwie, a tym samym mogli odkrywać i przyjmować jedyny fundament jedności Kościoła, Jezusa Chrystusa. Stwierdzenie szczególnej roli apostołów w życiu Kościoła otwiera wielki rozdział rozważań dotyczących istoty urzędu apostolskiego, kapłaństwa i hierarchii oraz jego roli pośród chrześcijańskich wspólnot kościelnych.

\section{E. ŚWIADOMOŚĆ I REALIZACJA JEDNOŚCI KOŚCIOŁA NA PRZESTRZENI WIEKÓW}

Kościół wypracował w swojej historii wiele środków, które stały się szczególnymi znakami troski o jedność. Są nimi nade wszystko: modlitwa, wymiana korespondencji pomiędzy Kościołami, synody i sobory.

Modlitwa o jedność. Pierwszym, który modlił się o jedność chrześcijan, był sam Jezus Chrystus. W trosce o zachowanie woli Pana Jego wyznawcy już od początków angażowali się modlitewnie w to duchowe dzieło towarzyszące nieustannie świadkom Jezusa szczególnie w chwilach zagrożenia jedności czy też nawet jej niszczenia ${ }^{26}$.

Wymiana korespondencji. Typową formą obrony przed rozłamami i umacniania jedności pomiędzy Kościołami była w pierwszym okresie wczesnego

\footnotetext{
24 Por. J. Stępień, Teologia św. Pawta, Warszawa 1979, s. 267.

25 Por. tamże, s. 416nn; K. Romaniuk, Soteriologia św. Pawta, Warszawa 1983, s. 213.

26 Por. A. Napiórkowski, Jedność konsekrowana, Kraków 2002, s. 62-68.
} 
chrześcijaństwa obfita korespondencja między wspólnotami. Wspólnoty (gminy) przesyłały opisy męczeństwa swoich sławnych członków, kierowały listy z podziękowaniami czy też ostrzeżeniami przed herezjami oraz upomnieniami. Przykładem takiego upomnienia jest skierowany do podzielonej i skłóconej wspólnoty wiernych List do Koryntian św. Klemensa Rzymskiego z ok. 96 r. W piśmie tym nakazuje się przywrócenie jedności, której istota oparta jest na prawdzie o sukcesji apostolskiej, będącej pochodzenia Boskiego: Chrystus otrzymaną od Ojca władzę przekazał apostołom - swoim następcom. Zadaniem zaś zwierzchników Kościołów, a zwłaszcza biskupa Rzymu, jest dbałość o jedność całej wspólnoty chrześcijan ${ }^{27}$. Klemens jako biskup Rzymu (92-101) jednoznacznie stwierdza, że rozłamy w hierarchii są równoznaczne z rozrywaniem Ciała Chrystusa, czyli Kościoła:

Skąd u was kłótnie, namiętności, podziały, rozłamy a nawet wojny? Czyż nie mamy wszyscy jednego Boga i jednego Ducha, który został na nas wylany? I czyż nie jedno jest nasze powołanie w Chrystusie? Dlaczego rozdzieramy i ćwiartujemy członki Chrystusowe? Dlaczego buntujemy się przeciw własnemu ciału i popadamy w taki obłęd, iż wydajemy się zgoła zapominać, że jesteśmy członkami jedni drugich ${ }^{28}$ ?

Podobne świadectwo, wyrażone w sposób pozytywny, zostało zawarte w Nauce dwunastu apostotów (ok. 100 r.): „Jak ten łamany chleb rozsiany był po górach, a zebrany stał się czymś jednym, tak niech zbierze się Kościół Twój z krańców ziemi w jedno Królestwo Twoje"29.

Z tego samego okresu pochodzi świadectwo troski o jedność Kościoła, zawarte w listach św. Ignacego Antiocheńskiego (107 r.) skierowanych do Kościołów w Małej Azji (z wyjątkiem listu do wiernych w Rzymie): w Efezie, Magnezji, Tralleis, Filadelfii, Smyrnie i do biskupa Polikarpa. Jedność ta powinna mieć charakter trynitarno-chrystologiczny, którego fundament stanowi relacja Syna z Ojcem oraz współistnienie bóstwa i człowieczeństwa w Chrystusie. Przez naśladowanie Chrystusa chrześcijanie mają tworzyć wspólnotę z Bogiem i między sobą. Największym zagrożeniem dla jedności są herezje, które zniekształcając prawdę o Bogu, niszczą także miłość, na której Kościół się wspiera ${ }^{30}$. Szczególnie wyraźnie św. Ignacy pisze o tym w Liście do Kościota w Filadelfi:

27 Por. M. Starowieyski, Interwencja biskupa Rzymu - sw. Klemens Rzymski, [w:] Pierwsi swiadkowie, Kraków 1988, s. 56nn.

${ }_{28}$ Św. Klemens Rzymski, List do Kościota w Koryncie, XLVI, 5-7,\{w:] Pierwsi świadkowie, dz. cyt., s. 93.

${ }^{29}$ Nauka dwunastu apostotów, IX, 4, [w:] Pierwsi świadkowie, dz. cyt., s. 46.

${ }_{30}$ Por. M. Starowieyski, Wotanie o jedność - św. Ignacy Antiocheński, [w:] Pierwsi świadkowie, dz. cyt., s. 128 . 
Starajcie się mieć tylko jedną Eucharystię. Jedno tylko jest Ciało Pana naszego Jezusa Chrystusa i jeden tylko kielich, którym jednoczymy się z Krwią Jego, i jeden tylko ołtarz ofiarny, a więc również jeden tylko biskup, otoczony prezbiterami i diakonami, współsługami swoimi. Jeśli zachowacie tę jedność, wówczas wszystkie wasze uczynki będą zgodne z wolą Boga [...].

A jednak świadczę o tym, za którego dźwigam kajdany, że nie dowiedziałem się tego z ust ludzkich. To Duch mi podszepnął, mówiąc: „Bez biskupa nic nie czyńcie, ciała swego strzeżcie niby świątyni Bożej, miłujcie jedność, unikajcie rozłamów, naśladujcie Jezusa Chrystusa tak, jak On naśladował swego Ojca”31.

Synody. W miarę rozwoju liczebnego i terytorialnego, zwłaszcza od połowy II wieku, pojawiły się w Kościele zjawiska zagrażające jedności na skalę o wiele większą, niż dotychczasowe rozłamy mające charakter lokalny czy też trwające prześladowania ${ }^{32}$. Chodziło o herezję montanizmu, problem daty wspólnego świętowania Wielkanocy w całym Kościele, sprawę tzw. lapsi - chrześcijan upadłych w czasie prześladowań i formy ich powrotu do Kościoła, a także spór o ważność chrztu udzielanego przez heretyków. Wtedy też, w drugiej połowie II wieku, pojawiły się w życiu Kościoła synody (gr. synodos - zebranie), zgromadzenia biskupów jednej lub kilku prowincji. Ruch synodalny zrodził się z poczucia świadomości, że pewne problemy wymagają wspólnego omówienia w duchu jedności pomiędzy biskupami jako następcami apostołów. Dlatego starano się o jak najliczniejsze i najbardziej reprezentatywne uczestnictwo w synodach. Liczbę biskupów zwiększano, przesyłając akta synodalne do podpisu nieobecnym. Im ważniejszej sprawy decyzja dotyczyła, tym bardziej zabiegano o jednomyślność.

Wzorem dla wszystkich synodów, soborów i innych spotkań pozostanie tzw. sobór jerozolimski, opisany w 15 rozdziale Dziejów Apostolskich. Słowa z dekretu apostołów tegoż zgromadzenia: „Postanowiliśmy zaś - my i Duch Święty” $(15,28)$ stały się podstawą teologii rozwiązań soborowych, do której nawiąże Kościół w następnych soborach i przy innych rozstrzygnięciach doktrynalnych.

Przykładem może być synodalna działalność papieża Wiktora I (ok. 190 r.), który inicjował zebrania w różnych miejscach (w Efezie, Poncie, Palestynie) na temat nauki o jedności dzieła zbawienia Jezusa Chrystusa i w związku ze sprawą daty świętowania Wielkanocy. Biskup Kartaginy, św. Cyprian (258), chcąc określić model postępowania wobec upadłych (lapsi), pisał do kapłanów rzymskich: „Mam zamiar zwołać zebranie licznych biskupów i nie bez waszej rady wszystko uregulować i zreformować”33.

31 Św. Ignacy Antiocheński, List do Kościota w Filadelfi, 4 i 7, [w:] ALP, t. 1, s. 27n.

32 Por. K. Schatz, Sobory powszechne. Punkty zwrotne w historii Kościoła, Kraków 2001, s. $15 \mathrm{nn}$.

33 Cyt. za: H. Jedin, Kleine Konzilsgeschichte, Basel-Freiburg-Wien 1959, s. 11. 
$\mathrm{Na}$ uwagę zasługują też synody w Antiochii z 264 i 268 r., na których potępiono naukę Pawła z Samosaty. Zebrani biskupi byli świadomi, że ich decyzje przekraczają ramy jednej prowincji i mają znaczenie dla całego chrześcijaństwa. Skierowali przeto listy do biskupa Rzymu - Dionizego i Aleksandrii - Maksyma oraz do biskupów całego Kościoła, które informowały o treści i przebiegu obrad. Synody te, gromadzące pasterzy z całego chrześcijańskiego Wschodu, podjęły też pierwsze próby określenia nauki o Trójcy Świętej i Jezusie Chrystusie, co miało wielkie znaczenie dla formułowania wspólnego wyznania wiary ${ }^{34}$.

Synody odgrywały wielką rolę w procesach reformy i odnowy Kościoła, jak to miało miejsce choćby po Soborze Trydenckim. Po Soborze Watykańskim II stały się jednym z głównych środków jego recepcji tak w wymiarze Kościoła powszechnego, jak i Kościołów lokalnych ${ }^{35}$.

Sobory. Od początku IV w. w życiu Kościoła na czoło środków budowania jedności wysunęły się synody powszechne, które, nazwane soborami, podejmowały decyzje dotyczące wiary i życia całej wspólnoty wierzących i były potwierdzane przez biskupa Rzymu. Pierwszym uznanym soborem powszechnym było spotkanie biskupów w Nicei, obradujące od 20 maja do 25 czerwca 325 r.

Siedem pierwszych soborów przypada na pierwsze tysiąclecie chrześcijaństwa, a więc czas, kiedy Kościół nie był jeszcze podzielony. $Z$ tego powodu ich rozstrzygnięcia mają wielkie znaczenie w ekumenicznych zabiegach o lepsze zrozumienie i jedność Wschodu z Zachodem ${ }^{36}$. Po schizmie wschodniej (1054 r.) idea spotkań soborowych była kontynuowana w Kościele katolickim, który wylicza w swojej historii 21 soborów powszechnych. Ich waga doktrynalna, dyscyplinarna i duszpasterska była różna. Obok takich, które precyzowały naukę Kościoła w ważnych sprawach i na całe stulecia określały praktykę liturgiczną, prawną i duszpasterską (jak Sobór Trydencki 1545-1563 wyjaśniający naukę o Piśmie Świętym i Tradycji, o grzechu pierworodnym i usprawiedliwieniu, o sakramentach i ofierze Mszy świętej, o kulcie świętych oraz wprowadzający daleko idące reformy instytucjonalne), były i takie, których decyzje ograniczały się do bieżących spraw politycznych ${ }^{37}$.

34 Por. J. Daniélou, Od początków do końca trzeciego wieku, [w:] Historia Kościota, t. 1, dz. cyt., s. $171-175$.

35 Por Dekret o pasterskich zadaniach biskupów w Kościele, 36; KPK kan. 342-348; Jan Paweł II, Encyklika „Redemptor hominis“, 5.

${ }^{36}$ Pełny tekst oryginalny tychże soborów, oraz ówczesny przekład łaciński i tłumaczenie polskie [w:] A. Baron, H. Pietras (red.), Dokumenty Soborów Porwszechnych. Tekst grecki, tacinski, polski. t. 1: 325-787, Kraków 2001.

37 Np. Sobór Lioński I w 1245. za papieża Innocentego IV zajął się detronizacją cesarza Fryderyka II, por. H. Jedin, Kleine Konzilsgeschichte, dz. cyt., s. 136nn. 
Zwołany w 1985 r., dwadzieścia lat po zakończeniu Vaticanum II, Nadzwyczajny Synod Biskupów w Rzymie przypomniał jego znaczenie w życiu Kościoła obecnego czasu ${ }^{38}$. Sposób odczytania nauki soborowej podano w krótkiej formule, która przypomina treść czterech wielkich Konstytucji, będących osią i kluczem całego Vaticanum II: Ecclesia (KK) - sub verbo Dei (KO) - mysteria Christi celebrans (KL) - pro salute mundi (KDK) (Kościół - kierowany słowem Bożym - sprawuje tajemnice Chrystusa - dla zbawienia świata). Przypomniano tu, że jedynym tematem Soboru jest Kościół (Lumen gentium), który jest kierowany słowem Bożym i temuż słowu służy (Verbum Dei), celebruje tajemnice Chrystusa i ma w nich swoje źródło (Sacrosanctum Concilium), będąc posłanym dla zbawienia świata (Gaudium et spes) ${ }^{39}$. To spojrzenie na Kościół staje się też kluczem do kontynuowania reform soborowych.

Katolicka jedność jest bowiem wyjątkiem w skali świata i to nie tylko ze względu na nieprzerwaną dwutysiącletnią historię. Chodzi w niej o przekraczające wszelkie granice państwowe, kulturowe i cywilizacyjne powiązanie religii i instytucji. Stąd też kształt jedności wewnątrzkościelnej ma znaczenie powszechne ${ }^{40}$. Kościół jako sakrament jedności w świecie jest też i dla świata, jak to stwierdza Gaudium et spes już w swoim tytule. Odnowiona instytucja synodów, wypracowanie sprawniejszego modelu współpracy pomiędzy Kościołem powszechnym a Kościołami lokalnymi, rola tych wspólnot w wymiarze kontynentalnym, regionalnym czy krajowym i ich łączność z biskupem Rzymu, to tylko niektóre sprawy, już istniejące i nabierające cech ogólnokościelnych ${ }^{41}$.

\section{F. RUCH EKUMENICZNY A JEDNOŚĆ KOŚCIOŁA}

Za początek zorganizowanego ruchu ekumenicznego uważa się pierwszą Międzynarodową Konferencję Misyjną w Edynburgu w 1910 r. Tam też tkwią korzenie działającej od 1948 r. Światowej Rady Kościołów, której celem jest realizacja idei jedności między chrześcijanami. Rada ta obecnie skupia ponad trzysta

38 Por. W. Kasper, Die bleibende Herausforderung durch das II. Vatikanische Konzil. Zur Hermeneutik der Konzilsaussagen, [w:] tenże, Theologie und Kirche, Mainz 1987, s. 290-299.

39 Der Apostolische Stubl 1985. Ansprachen, Predigten und Botschaften des Papstes. Erklärungen der Kongregationen, Libreria Editrice Vaticana 1985, s. 1859-1882.

40 Por. K. Schatz, Papsttum - Ärgernis und Konkretion des Katholischen, [w:] W. Brandmüller (red.), Das eigentlich Katholische, Aachen 1997, s. 229n.

41 Por. G. Greshake, Weltkirche und Ortskirche. Bemerkungen zu einem problematischen Verbältnis, [w:] „Theologie und Glaube” 91 (2001), s. 528-542; S. Pié-Ninot, Wprowadzenie do eklezjologii, dz. cyt., s. 83n; W. Kasper, Das Verhältnis von Universalkirche und Ortskirche. Freundschaftliche Auseinandersetzung mit der Kritik von Joseph Kardinal Ratzinger, [w:] „Stimmen der Zeit“ (2000), s. 795-804. 
Kościołów protestanckich i prawosławnych. Kościół katolicki prowadzi dialog ze Światową Radą Kościołów poprzez powołany przez Jana XXIII w 1960 r. Sekretariat do spraw Jedności Chrześcijan ${ }^{42}$.

Sobór Watykański II podjął sprawę jedności Kościoła Jezusa Chrystusa jako naturalną konsekwencję odnowionej świadomości eklezjalnej w swoim najważniejszym dokumencie, Konstytucji dogmatycznej o Kościele, w której pozytywnie określił kościelność innych wyznań chrześcijańskich i wzajemne relacje przez termin communio ${ }^{43}$. Postawę ekumeniczną określił Vaticanum II w Dekrecie o ekumenizmie. Stwierdza w nim, że rozłamy nastąpiły z winy zarówno katolików, jak i niekatolików, i dlatego też zwraca się w imieniu Kościoła katolickiego do innych Kościołów z prośbą o wybaczenie, jednocześnie ze swej strony takiego wybaczenia udzielając ${ }^{44}$.

Współczesnych niekatolików nie można winić za dawne rozłamy ani też uważać za heretyków czy schizmatyków. Herezja czy schizma łączy się bowiem $z$ ciężką winą osobistą. Bracia odłączeni pozostają w rzeczywistej, choć niedoskonałej, wspólnocie z katolikami, którą stwarza przede wszystkim wiara w Jezusa Chrystusa jako Boga i Zbawiciela, sakrament chrztu, Pismo Święte i wiele elementów wspólnej Tradycji ${ }^{45}$.

Kościół w wyznaniu wiary określono jako „jeden”. Rzeczywistość wskazuje jednak, że jest on podzielony, a chrześcijanie w swoich konfesjach podają własne rozumienie tej cechy credo ${ }^{46}$.

Kościół rzymsko-katolicki wskazuje na trzy podstawowe elementy jedności: wiarę, kult (sakramenty) i wspólnotę kościelnego życia pod przewodnictwem uprawnionych pasterzy. Te trzy, już przez św. Roberta Bellarmina (1542-1621) wskazane elementy, zostały powtórzone w Dekrecie o ekumenizmie, gdzie jest mowa, że Jezus Chrystus buduje swój Kościół w wyznaniu jednej wiary, we wspólnym świętowaniu służby Bożej, w braterskiej zgodzie Bożej rodziny pod przewodem biskupów we wspólnocie z następcą Piotra jako głowy ${ }^{47}$.

Kościół prawosławny akceptuje w zasadzie katolicką naukę o jedności. Różnica polega na tym, że prawosławni eklezjologiczną zasadę communio akcentują we wspólnocie Kościołów opartej na kolegialności biskupów bez uwzględ-

${ }^{42}$ Por. A. Napiórkowski, Zagadnienia ekumeniczne, Kraków 2001, s. 75-77.

43 Por. KK 8.

44 Por. DE 7.

45 Por. A. Napiórkowski, Zagadnienia ekumeniczne, dz. cyt., s. 124-129.

${ }^{46}$ Por. M. M. Garjo-Guembe, Gemeinschaft der Heiligen. Grund, Wesen und Struktur der Kirche, Düsseldorf 1988, s. 118nn.

47 Por. DE 2. 
nienia roli Piotra. Ich koncepcję podzielają wspólnoty anglikańskie i Kościól starokatolicki.

Kościoły poreformacyjne chcą widzieć jedność bezpośrednio we wspólnocie Kościołów lokalnych, co wynika z nauki Wyznania Augsburskiego, gdzie Kościół jest:

zgromadzeniem wszystkich wierzących, w którym jest głoszona czysta Ewangelia i gdzie są według niej udzielane sakramenty. Do jedności Kościoła nie jest konieczne zachowanie podobnych ceremonii, które zostały wprowadzone przez ludzi,jak to stwierdza Paweł w Liscie do Efezjan w 4 rozdziale ${ }^{48}$.

Współczesne problemy ekumeniczne są bezpośrednio związane z zadaniem nowego odczytania posługi biskupa Rzymu na rzecz jedności Kościoła, na co wskazał Jan Paweł II w 1995 r.:

Jestem przekonany, że ponoszę w tej dziedzinie [jedności wszystkich chrześcijańskich Wspólnot] szczególną odpowiedzialność, która polega przede wszystkim na dostrzeganiu ekumenicznych dążeń większości chrześcijańskich Wspólnot i na wsłuchiwaniu się w kierowaną do mnie prośbę, abym znalazł taką formę sprawowania prymatu, która nie odrzucając bynajmniej istotnych elementów tej misji, byłaby otwarta na nową sytuację. [...] Modlę się gorąco do Ducha Świętego, oby obdarzył nas swoim światłem i oświecił wszystkich pasterzy i teologów naszych Kościołów, abyśmy wspólnie poszukiwali takich form sprawowania owego urzędu, w którym możliwe będzie realizowanie uznawanej przez jednych i drugich posługi miłości ${ }^{49}$.

Zarówno treść tego dokumentu, jak i całą służbę papieża Jana Pawła II na rzecz jedności Kościoła dobrze oddają jego słowa wypowiedziane we Wrocławiu na spotkaniu ekumenicznym:

Wsłuchując się w głos Ducha Świętego, Kościoły i Wspólnoty Kościelne czują się nieodwołalnie wezwane do poszukiwania coraz głębszej, nie tylko wewnętrznej, ale także widzialnej jedności. Jedności, która stałaby się znakiem dla świata, aby świat poznał i aby świat uwierzył. $Z$ drogi ekumenizmu nie ma odwrotu! ${ }^{50}$.

48 Art. nr 7: cyt. za: H. Schütte, Kirche im ökumenischen Verständnis, Paderborn 1991, s. 81, por. M. M. Garjo-Guembe, Gemeinschaft der Heiligen, dz. cyt., s. 119

${ }^{49}$ Ut unum sint, 95.

${ }^{50}$ Przemórwienie wygtoszone w czasie nabożeñstwa ekumenicznego w Hali Ludowej 31 maja 1997 r., [w:] Drogowskazy dla Polaków Ojca Świętego Jana Parwta II, t. III, Kraków 1999, s. 301. 


\section{C. Świętość}

Znamię świętości zawsze odnosi się do Boga i należy do istoty religijności, która przejawia się nade wszystko w postawie uwielbienia, całkowitego podporządkowania i naśladowania Jego doskonałości ${ }^{51}$. Stąd Kościół, powstały i działający na ziemi z Jego woli, w swojej istocie będzie określany przez znamię świętości.

\section{Treść pojęcia}

\section{A. KOŚCIÓŁ NIEZACHWIANIE ŚWIĘTY}

Znamię świętości wyznacza różnicę pomiędzy socjologiczno-społecznym a sakramentalnym rozumieniem Kościoła ${ }^{52}$. Wskazuje, że choć jest on obecny w świecie, jednak z niego nie pochodzi (por. J 17, 11.14n). Mimo że ma kształt instytucjonalny, jest jednak oddzielony od spraw ziemskich dla służby Bogu i Jego Królestwu ${ }^{53}$. To oddzielenie nie jest tylko pewnym przyporządkowaniem rzeczowo-celowym, lecz ma fundament ontologiczny, zawarty w samej jego istocie, której podstawę stanowi łączność ze swoim świętym Założycielem, jak to stwierdza Vaticanum II:

Kościół [...] uznawany jest przez wiarę za niezachwianie święty. Albowiem Chrystus, Syn Boży, który wraz z Ojcem i Duchem Świętym doznaje czci jako «sam jeden Święty», umiłował Kościół jako oblubienicę swoją, siebie samego zań wydając, aby go uświęcić; złączył go też ze sobą jako ciało swoje i hojnie obdarzył darem Ducha Świętego na chwałę Bożąa

Określenie soborowe wskazuje na potrójną pieczęć świętości Kościoła: uświęcenie go przez Jezusa Chrystusa, nierozdzielną łączność z Nim i ubogacenie wylaniem swego Ducha. Kościół jest więc „świętym ludem Bożym”55, tak jak poszczególni jego członkowie (por. Dz 9, 13; 1 Kor 6, 1; 16, 1).

Ontologiczna świętość Kościoła uwidacznia się przez dobra zbawienia, w które został on z woli Jezusa Chrystusa trwale wyposażony dla dalszego ich przekazywania. Są nimi: prawdy wiary, sakramenty nowego życia, posługi i urzędy ${ }^{56}$. Oznacza to też najważniejsze jego zadanie, jakim jest „uświęcanie

51 Świętość uważana jest za najstarszy atrybut Kościoła, por. W. Kasper, Kościół, dz. c. s. 292n.

52 Por. H. Seweryniak, Święty Kościót powszedni, dz. cyt., s. 206.

53 Por. W. Kasper, Katholische Kirche, [w:] Staatslexikon. Recht, Wirtschaft, Gesellschaft, t. 3, Freiburg im Br. 1987, k. 329.

${ }^{54}$ KK 39.

55 KK 12.

56 Por. H. Schütte, Kirche im ökumenischen Verständnis, Paderborn 1991, s. 102. 
człowieka w Chrystusie i uwielbienie Boga" ${ }^{57}$. W tym znaczeniu wyznanie, że Kościól jest święty, ma prowadzić do wdzięczności za dar uświęcającego działania Boga poprzez praktyczną odpowiedź w realizowaniu „subiektywnej” świętości wszystkich chrześcijan ${ }^{58}$, która dokonuje się na drodze naśladowania Chrystusa.

Szczególnym znakiem świętości Kościoła, a zarazem jego wiarygodności, są niektórzy jego wierni - kanonizowani, czyli uroczyście wskazani jako ci, którzy doskonale wypełnili ewangeliczną drogę Jezusa Chrystusa. Dokonując tego aktu, Kościól wskazuje na moc Ducha Świętego, który nieustannie w nim działa oraz umacnia nadzieję swoich wiernych, dając im świętych jako wzory i orędowników ${ }^{59}$. Święci byli i są w całej historii zaczynem kościelnej reformy i nieustannej odnowy, a przez to świadczą, że „świętość Kościoła jest tajemniczym źródłem i nieomylną miarą jego apostolskiego zaangażowania oraz misyjnego zapału” ${ }^{60}$. Równocześnie Kościół podkreśla, że wierni starający się usilnie przezwyciężyć grzech i wzrastać w świętości, wpatrują się w osobę Niepokalanej Maryi Panny, w której już osiągnął doskonałość i w Niej cały jest święty ${ }^{61}$.

Znamię świętości Kościoła zawiera też prawdę, że jest on niezniszczalny i nie o mylny. Potwierdzają to wszystkie Kościoły chrześcijańskie, opierając się na nowotestamentalnych świadectwach (por. Mt 28, 20; J 16, 13; Mt 16, 18). Stąd wynika przekonanie, że Kościół, będąc znakiem i narzędziem zwycięskiego i ponadczasowego działania Boga, pomimo grzechu i słabości, nie może nigdy wypaść z łaski Bożej: jego istnienie jest niezniszczalne, a kontynuacja i trwanie zagwarantowane przez Bożą obietnicę. Prowadzi to do przeświadczenia o pozostawaniu pewnym znakiem łaski Bożej w świecie pomimo grzeszności: kościelne sakramenty są niezależne od godności szafarzy, a nauka - przy zachowaniu określonych warunków - jest bezbłędna i nieomylna. Kościół katolicki potwierdza, że jego niezniszczalność i nieomylność konkretyzuje się w Urzędzie Nauczycielskim papieża i soboru ${ }^{62}$.

Pełną treść znamienia świętości Kościoła uwypukla jego wymiar wspólnotowo-eschatologiczny ${ }^{63}$, podkreślając prawdę o wspólnocie obcowania świętych ${ }^{64}$.

$57 \mathrm{KL} 10$.

58 Por. KK 39-42.

59 Por. KK 40; 48-51.

${ }^{60}$ Jan Paweł II, Adhortacja Christifideles laici, 17.

${ }_{61}$ Por. KK 65.

${ }^{62}$ Por. S. Wiedenhoffer, Ekklesiologie, [w:] Handbuch der Dogmatik, t. 2, dz. cyt., s. 122n.

63 Por. KK 48-51.

${ }^{64}$ Por. Kongregacja Nauki Wiary, List do Biskupów Kościota Katolickiego o niektórych aspektach Kościota pojętego jako Komunia, Watykan 1992, s. 6-7. 
Ontologiczny dar doskonałej i nieskazitelnej świętości, dany Kościołowi w jego Założycielu, spotyka się z rzeczywistością grzechu i słabości, którymi skażeni są wchodzący doń członkowie. Jest to poniekąd jego „normalny” stan i zarazem zadanie: aby zagarniać w sieci zbawienia coraz nowe, naznaczone grzechem pokolenia ludzkie, wzywać je do nawrócenia i kierować do większej świętości. W tym znaczeniu grzech nie jest znakiem słabości Kościoła i zgorszeniem dla świata, ale stanowi wyraz jego mocy zbawczej, niosącej światu i człowiekowi prawdziwe wyzwolenie i zbawienie. Ujawnianie w nim grzechu człowieka jest związane z jego usuwaniem i leczeniem zranionej natury ludzkiej. Dlatego też Kościół, jak dobry lekarz, za wzorem Jezusa Chrystusa, cierpliwie, ale też i wytrwale prowadzi do coraz większej doskonałości swoich członków, którzy w ,jakiejkolwiek sytuacji życiowej oraz stanu powołani są przez Pana, każdy na właściwej sobie drodze, do świętości doskonałej, jak i sam Ojciec doskonały jest”"5.

Kościół może uświęcać, bo sam jest święty Chrystusem:

A podczas gdy Chrystus, „święty, niewinny, niepokalany”, nie znał grzechu, lecz przyszedł dla przebłagania jedynie za grzechy ludu, Kościół obejmujący w łonie swoim grzeszników, święty i zarazem ciągle potrzebujący oczyszczenia, podejmuje ustawicznie pokutę i odnowienie ${ }^{66}$.

Ponieważ wszyscy członkowie Kościoła muszą uznać się za grzeszników, wspólnie też, wsparci łaską jego świętości, podejmują dzieło nawracania i uświęcania, jak to wyraził św. Paweł VI:

Kościół jest więc święty, chociaż w swoim łonie obejmuje grzeszników, albowiem cieszy się nie innym życiem, jak życiem łaski; jeśli jego członki karmią się nią, uświęcają się, jeśli zaś odwracają się od niej, obciążają się grzechami i winami, które stoją na przeszkodzie w rozszerzaniu się jego promiennej świętości. Dlatego Kościół cierpi i czyni pokutę za te grzechy, mając władzę uwalniania od nich swoich synów przez Krew Chrystusa i dar Ducha Świętego ${ }^{67}$.

Kościół, który faktycznie stanowi wspólnotę grzeszników, na mocy świętości w nim będącej jest wezwany do ustawicznego oczyszczania się, nawracania i uświęcania; nieustannie się odnawia. Sobór Watykański II stwierdza, że cały

\footnotetext{
${ }^{65} \mathrm{KK} 48$.

${ }^{66} \mathrm{KK} 8$

${ }^{67}$ Paweł VI, Wyznanie wiary Ludu Bożego, 19.
} 
Kościół jest święty i równocześnie potrzebuje odnowienia. Nie używając terminu grzeszny Kościót, nawiązuje do starej tradycji ${ }^{68}$, według której grzech ma wymiar nie tylko indywidualny, wewnętrzny, ale także kolektywny, materialny i ontologiczny. Wyznanie grzechów i prośba o ich przebaczenie są centralnymi aktami Kościoła. Znalazło to szczególny wyraz w wyznaniu papieża Hadriana VI w 1523 r. po podziale Kościoła Zachodniego ${ }^{69}$ i św. Jana Pawła II, który przygotowując Kościół na przeżycie jubileuszu tajemnicy Wcielenia w 2000 r., widział fundament pojednania chrześcijan najpierw w uznaniu i wyznaniu grzechów członków swojego Kościoła, aby przez nawrócenie, przebaczenie modlitwę i cierpliwy dialog uczynić następne kroki na drodze ekumenizmu ${ }^{70}$.

\section{Refleksja biblijno-historyczna}

\section{A. W STARYM TESTAMENCIE}

Świętość podstawowe znaczenie uzyskuje w semickim określeniu „rzeczy świętej”, „świętowania” (godeš), które w swoim źródłosłowie oznacza „ciąć”, „oddzielać”. W religijnym znaczeniu oznacza więc oddzielenie, inność, mającą swoje jedyne odniesienie w trzykroć świętym Bogu, którego objawienie jest dla Jego ludu wezwaniem do świętości, do życia według Jego świętych praw i potwierdzania przez odnawianie z Nim przymierza. Choć objawienie świętości

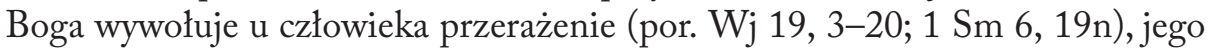
celem jest błogosławieństwo i wyzwolenie $z$ niewoli duchowej i zewnętrznej. Objawienie świętości Boga zawsze stanowi znak Jego miłości i przebaczenia: „Nie chcę, aby wybuchnął płomień mojego gniewu... albowiem Bogiem jestem, nie człowiekiem; pośrodku ciebie jestem Ja - Święty" (Oz 11, 9).

Czynna obecność Boga sprowadza na lud nie tylko świętość rytualną, lecz także zobowiązanie do świętości moralnej, płynącej z zachowania Prawa (por. Kpł 23, 31nn). Przez to uświęcenie cały lud i każdy jego poszczególny członek uzyskuje godność bycia własnością Pana.

${ }_{68}$ Por. KK 5. 8. 9. 14. 40. 48. 65; DE 6.

69 „Wyznajemy szczerze, że to prześladowanie swojego Kościoła dopuścił Bóg z powodu grzechów ludzi, a szczególnie kapłanów i prałatów. Jesteśmy świadomi także i tego, że na Stolicy Świętej działo się w ostatnich czasach wiele godnego potępienia: nadużycia w sprawach duchowych, przekraczanie przykazań, tak, że wszystko to spowodowało oburzenie i gniew. Dlatego nie należy się dziwić, że choroba rozpleniła się z głowy na członki, od papieży na prałatów. My wszyscy, prałaci i duchowni, zeszliśmy z drogi...”, [w:] J. Lortz, E. Iserloh, Kleine Reformationsgeschichte, Freiburg 1969, s. 26.

70 Por. UUS 34. 
Przyjmując objawienie trzykroć świętego Boga, Izrael odpowiadał najpierw przekonaniem, że jego uświęcenie jest darem niedającej się wytłumaczyć miłości Boga. Dlatego powinien podejmować ciągły trud oczyszczania się i nawracania ku wierności Prawu i Przymierzu. Znakiem uświęcenia i zbliżenia do Boga jest nie tyle powtarzający się zewnętrzny rytuał składania ofiar, ale sprawiedliwość, posłuszeństwo i miłość (por. Iz 1, 4-20; Pp 6, 4-9). Doświadczenie niewierności Izraela Bożemu wezwaniu i słabości człowieka wobec postawionych wymagań było powodem nowych pytań o skuteczność uświęcenia ludu. Z założenia bowiem Objawienie starotestamentalne miało charakter przygotowawczy dla Nowego Przymierza, które będzie zdolne uczynić człowieka doskonałym (por. $\mathrm{Hbr} 7,19 ; 9$, 9; 10, 1). Potwierdzali to prorocy, którzy zapowiadali pełnię objawienia się mocy i świętości Boga w czasach ostatecznych.

\section{B. W OSOBIE I ZAMYŚLE CHRYSTUSA}

Objawienie się Boga w Jezusie Chrystusie jest manifestacją pełni Jego świętości. Mówią o tym słowa zwiastowania: przychodzący na świat Mesjasz, Święty, jest poczęty z Ducha Świętego i „zostanie nazwany Synem Bożym” (Łk 1, 35; Mt 1, 18). Świętość Zbawiciela jest ściśle powiązana z Jego Boskim synostwem i obecnością w Nim Ducha Świętego. Zostaje to potwierdzone podczas chrztu w Jordanie, kiedy sam Bóg Ojciec oznajmia, że Jezus to Jego „umiłowany Syn”, który otrzymuje namaszczenie Duchem Świętym (Łk 3, 22; Dz 10, 38). Świętość Jezusa potwierdzają wyrzucane przez Niego duchy nieczyste, obwołując Go „Świętym Boga” lub „Synem Bożym” (Mk 1, 24; 3, 11). Świętość Jezusa jest identyczna ze świętością Boga, Jego Ojca (por. J 17, 11). Ta właśnie ona sprawia, że Jezus miłuje swoich uczniów aż do udziału w swojej chwale otrzymanej od Ojca; aż do oddania za nich własnego życia: „A za nich Ja poświęcam w ofierze samego siebie, aby i oni byli uświęceni w prawdzie" (J 17, 19) ${ }^{71}$.

Uświęcające działanie Jezusa wobec uczniów jest procesem, który ma swoje istotne etapy, jak wybór, stałe uczestnictwo w Jego życiu, słuchanie Jego nauki i udział w Jego czynach. Źródłem i fundamentem uświęcenia staje się, po tym koniecznym etapie przygotowania, przyjęcie ofiary krzyżowej, wiara w Jego zmartwychwstanie i otwarcie się na działanie Ducha Świętego. Powołując uczniów do wspólnoty z sobą i dając tym samym podwaliny pod wspólnotę Kościoła jako nowego ludu, zostawia mu Chrystus w testamencie całe swoje dzieło i siebie samego, aby mógł dalej kontynuować posługę uświęcania człowieka i świata. Pierwsi apostołowie byli świadomi tego, że nowy lud Boży, Kościól, jest święty,

${ }^{71}$ Por. J. de Fraine, Święty, [w:] X. Leon-Dufour (red), Stownik Teologii Biblijnej, Poznań 1994, s. 975 n. 
bo nabyty „drogocenną krwią Chrystusa, jako baranka niepokalanego i bez zmazy”" (1 P 1,19), co znajduje potwierdzenie w wezwaniu do chrześcijan:

Wy jesteście wybranym plemieniem, królewskim kapłaństwem, świętym narodem, ludem Bogu na własność przeznaczonym, abyście ogłaszali dzieła potęgi tego, który was wezwał z ciemności do przedziwnego swojego światła (1 P 2, 9).

Gwarancją świętości Kościoła jest jego trwała łączność z Głową, Chrystusem (por. Tes 1, 18), który

umiłował go i wydał za niego samego siebie, aby go uświęcić, oczyściwszy obmyciem wodą, któremu towarzyszy słowo, aby sam stawił przed sobą Kościół jako chwalebny, nie mający skazy czy zmarszczki, czy czegoś podobnego, lecz aby był święty i nieskalany (Ef 5, 26-27).

Dar świętości umacnia namaszczenie Duchem Świętym i mocą (por. Dz 2, 33; 10, 38). Dlatego też chrześcijanie powinni znać godność i wielkość swojej wspólnoty, która jest mieszkaniem samego Boga. Posługując się obrazem stawiania rodzinnego domu, pisze św. Paweł do wspólnoty Kościoła w Efezie:

A więc nie jesteście już obcymi i przychodniami, ale jesteście współobywatelami świętych i domownikami Boga - zbudowani na fundamencie apostołów i proroków, gdzie kamieniem węgielnym jest Jezus Chrystus. W Nim zespalana budowla rośnie na świętą w Panu świątynię, w Nim także i wy wznosicie się we wspólnym budowaniu, by stanowić mieszkanie Boga przez Ducha (Ef 2, 19-22).

\section{W PIERWOTNYM KOŚCIELE}

Świadomości o świętości Kościoła towarzyszy u chrześcijan pamięć o grzeszności człowieka, który uświęca się powoli i nawet po włączeniu do świętej wspólnoty nieustannie potrzebuje nawrócenia i łaski ${ }^{72}$. Dzieło jednania dokonuje się przez posługę apostolsko-kapłańską, czyli nieustanne wzywanie do nawrócenia i przekazywanie „słowa jednania” (2 Kor 5, 19). Głoszenie napominania w imię Chrystusa do pojednania się z Bogiem i do świętego życia na Jego wzór jest nierozdzielnie związane z udzielaniem sakramentów chrztu (por. Mt 28, 19) i pokuty (por. J 20, 22-23) oraz sprawowaniem Eucharystii (por. 1 Kor 10, 14nn; $\operatorname{Hbr} 10,19 \mathrm{nn})$.

72 Na uwagę zasługują tu powtarzające się w pismach apostolskich tzw. katalogi grzechów, nałogów i słabości, które są znakiem nieustannej potrzeby nawrócenia i uświęcania. 
Owocem nawrócenia i uświęcania się ma być życie w czystości i prawdziwej miłości wzajemnej, do której wezwani są wszyscy chrześcijanie. One stają się istotnymi znakami świadectwa wiarygodności Kościoła, o czym mówi Apostoł Narodów:

A na koniec, bracia, prosimy i zaklinamy was w Panu Jezusie: według tego, coście od nas przejęli w sprawie sposobu postępowania i podobania się Bogu - jak już postępujecie stawajcie się coraz doskonalszymi! Wiecie przecież, jakie nakazy daliśmy wam przez Pana Jezusa. Albowiem wolą Bożą jest wasze uświęcenie: powstrzymywanie się od rozpusty, aby każdy umiał utrzymywać ciało własne w świętości i we czci, a nie w pożądliwej namiętności [...]. Niech nikt w tej sprawie nie wykracza i nie oszukuje brata swego [...]. Nie powołał nas Bóg do nieczystości, ale do świętości [...]. A więc kto to odrzuca, nie człowieka odrzuca, lecz Boga, który przecież daje wam swego Ducha Świętego. Nie jest rzeczą konieczną, abyśmy wam pisali o miłości braterskiej, albowiem Bóg was samych naucza, abyście się wzajemnie miłowali [...]. Wobec tych, którzy pozostają na zewnątrz, zachowujcie się szlachetnie (1 Tes 4, 1-6. 7-9.12).

\section{D. ŚWIADOMOŚĆ I REALIZACJA ŚWIĘTOŚCI NA PRZESTRZENI WIEKÓW}

Wyrażenie „święty Kościół” należy do najwcześniejszych jego określeń. Znajduje się między innymi u św. Ignacego z Antiochii, w Pasterzu Hermasa, w Martyrium śr. Polikarpa, u Hippolita i we wczesnych symbolach chrzcielnych ${ }^{73}$. Nie przestawano równocześnie wskazywać na grzechy, ciągle przez chrześcijan popełniane. Znalazło to wyraz w określeniach, jakie Kościołowi nadali niektórzy jego Ojcowie: dziewicy czystej i nierządnicy, świętego i splamionego (casta meretrix, Ecclesia mixta). Dla Ojców Kościoła wyznanie jego świętości było równocześnie wezwaniem do wyznania swoich grzechów i wejścia na drogę uświęcania, co znajdowało oparcie w świadomości trwałej jego łączności z Jezusem Chrystusem. Z tym też wiązało się wyjaśnienie postawy wobec grzeszników, zwłaszcza popełniających grzechy ciężkie czy zapierających się wiary w wyniku prześladowań.

Niezmienna w Kościele pozostała nauka o źródłach uświęcania, którym jest naśladowanie Jezusa Chrystusa w mocy Ducha Świętego według wskazań i przy pomocy środków, jakie podawał Kościół. Zawsze najważniejszym znakiem była pozytywna odpowiedź na wezwanie do nawrócenia, do doskonalenia się w życiu

73 Por, J. Auer, Die Kirche, Regensburg 1983, s. 251; P. Th. Camelot, Die Lehre von der Kirche. Väterzeit bis einschließlich Augustinus, Freiburg 1970, s. 60; S. Wiedenhoffer, Ekklesiologie, [w:] Handbuch der Dogmatik, t. 2, dz. cyt., s. $121 \mathrm{nn}$. 
duchowym i społecznym przez życie słowem Bożym i łaską sakramentów połączoną z osobistym wysiłkiem oraz pomocą wspólnoty kościelnej. Niezmienne też było przekonanie, że do świętości powołani są bez wyjątku wszyscy chrześcijanie. Znalazło to $\mathrm{m}$. in. wyraz w nauce o dwóch drogach, jak to stwierdza Didache z ok. 100 roku: „Dwie są drogi, jedna droga życia, a druga śmierci - i wielka jest różnica między nimi” ${ }^{74}$. Dla chrześcijanina właściwa jest tylko droga życia, czyli świętości. Nie ma możliwości pośredniej (tertium non datur), która zapewniałaby zbawienie.

Dzieje Kościoła świadczą też, że w poszczególnych okresach jego istnienia eksponowano różne elementy naśladowania Jezusa Chrystusa. W pierwszych trzech wiekach, co było związane z prześladowaniami chrześcijan, na pierwszy plan wysunęło się męczeństwo, jako najdoskonalszy sposób realizacji życia ewangelicznego. Takim świadectwem jest prośba św. Ignacego Antiocheńskiego do chrześcijan w Rzymie, by nie starali się przeszkodzić jego męczeńskiej śmierci, którą zgodnie $\mathrm{z}$ wyrokiem sądu miał ponieść na arenie cyrkowej, rzucony na pożarcie dzikim zwierzętom. W liście Do Kościota w Rzymie ok. 100 roku pisał:

Piszę do wszystkich Kościołów i wszystkim powtarzam, że ja umieram za Boga z własnej woli - jeśli tylko wy mi nie przeszkodzicie. Zaklinam was, nie bądźcie mi życzliwi nie w porę. Pozwólcie mi stać się żerem dla dzikich zwierząt, przez które mogę posiąść Boga. Pszenicą jestem Bożą, a zmielony zwierzęcymi zębami, okażę się czystym chlebem Chrystusa [...]. Wtedy naprawdę będę uczniem Jezusa Chrystusa, kiedy nawet ciała mego świat widzieć nie będzie ${ }^{75}$.

Ze świadectwem świętych męczenników szła w parze wielka cześć dla ich heroicznej postawy wobec przeciwności, jakie musieli znieść. $Z$ tego powodu zrodził się kult świętych, stawianych za wzór do naśladowania dla chrześcijan, a także orędowników przed Bogiem. Miejsca ich śmierci, a zwłaszcza ich groby stawały się punktem spotkań chrześcijan, szczególnie eucharystycznych, a z czasem także celem pielgrzymek. Świadectwo o takiej czci męczennika i jego relikwii znajduje się w opisie męczeństwa Polikarpa ze Smyrny, osiemdziesięciosześcioletniego biskupa, skazanego na śmierć ok. 155 roku:

Tak więc mogliśmy później zebrać jego kości, cenniejsze od klejnotów, droższe od złota, aby je złożyć w miejscu stosownym. Tam też, jeśli to będzie możliwe, pozwoli nam Pan spotykać się razem w weselu wielkim i radości, aby obchodzić rocznicę męczeństwa

74 Nauka dwunastu apostotów, I, 1, [w:] Pierwsi świadkowie, dz. cyt., s. 39.

75 IV, 1.3, [w:] Pierwsi świadkowie, dz. cyt., s. 158. 
Polikarpa jako dzień jego narodzin i w ten sposób wspominać tych, którzy walczyli przed nami, a zarazem ćwiczyć i przygotować tych, którzy będą walczyć w przyszłości ${ }^{76}$.

Obok męczenników pojawili się święci wyznawcy, chrześcijanie naśladujący Chrystusa przez życie według rad ewangelicznych, co wiązało się z różnymi formami życia pustelniczego i zakonnego, a stało się trwałym znakiem uświęcającej działalności Kościoła. Jego instytucjonalne początki, mające korzenie w Ewangelii i w życiu pierwotnej wspólnoty, są związane ze św. Pawłem I Pustelnikiem z Teb, św. Antonim opatem i Pachomiuszem na Wschodzie, a na Zachodzie ze św. Augustynem i św. Benedyktem z Nursji. Wpływ życia zakonnego na Kościół osiągnął swoje apogeum w średniowieczu, kiedy chrześcijan dzielono na zakonników oraz świeckich, do których zaliczano także biskupów i kler diecezjalny. Formy uświęcania się świeckich pochodziły nade wszystko z życia klasztorów przez różne związki w rodzaju trzecich zakonów czy konfraterni. Ludzie świeccy, odgrywający tak wielką rolę w pierwszych wiekach chrześcijaństwa, po okresie zapomnienia we wczesnym średniowieczu zostali zauważeni w oficjalnych dokumentach kościelnych na Soborze Laterańskim IV (1215 r., w związku z nałożeniem obowiązku rocznej spowiedzi i komunii św.). Znaczenie ich życia małżeńskiego, rodzinnego i zawodowego jako realizacji chrześcijańskiego powołania ukazywał w nowym świetle Franciszek Salezy (1567-1622). Jednak właściwe odkrycie roli świeckich w Kościele miało miejsce w początkach XIX wieku $\mathrm{w}$ związku $\mathrm{z}$ wzrastającym ich znaczeniem na polu obrony wiary, krzewienia kultury chrześcijańskiej i rosnącego zaangażowania w życiu politycznym. Ich rola, widziana najpierw jako przedłużenie ramienia hierarchii (co miało miejsce szczególnie w Akcji Katolickiej), została na nowo określona przez Vaticanum II (szczególnie w nauce o ludzie Bożym, o powszechnym kapłaństwie i o powołaniu wszystkich chrześcijan do świętości), a potwierdzona przez nauczanie Jana Pawła II, zwłaszcza w adhortacjach Familiaris consortio (1981) i Christifideles laici (1989).

\section{3. Świętość w Kościele katolickim dziś}

\section{A. KOŚCIÓ̇ UŚWIĘCAJĄCY SIĘ I UŚWIĘCAJĄCY}

Artykuł Credo mówiący o świętości Kościoła jest aktualny także i we współczesnej refleksji, w znaczeniu ontycznym, nad powszechnym powołaniem wiernych do świętości, nad współczesnymi modelami świętości oraz nowymi zadaniami w jej formowaniu. Szczególnym potwierdzeniem tej prawdy stała się działalność

${ }^{76}$ Męczeństwo śr. Polikarpa, XVIII, 1-3, [w:] ALP, t. 1, dz. cyt., s. 136. 
Jana Pawła II, wynoszącego na ołtarze całe rzesze świętych i błogosławionych. Wpisuje ona działanie Kościoła w perspektywę uświęcania i uświęcania się $^{77}$. W programie podanym dla Kościoła na nadchodzący czas papież-Polak stwierdza:

Sobór wyjaśnił, że nie należy mylnie pojmować tego ideału doskonałości jako swego rodzaju wizji życia nadzwyczajnego, dostępnego jedynie wybranym „geniuszom” świętości. Drogi świętości są wielorakie i dostosowanego do każdego powołania. Składam dzięki Bogu za to, że pozwolił mi beatyfikować i kanonizować w minionych latach tak wielu chrześcijan, a wśród nich licznych wiernych świeckich, którzy uświęcili się w najzwyklejszych okolicznościach życia. Dzisiaj trzeba na nowo z przekonaniem zalecać wszystkie dążenia do tej "wysokiej miary” zwyyczajnego życia chrześcijańskiego. Całe życie kościelnej wspólnoty i chrześcijańskich rodzin winno zmierzać w tym kierunku. Ale jest też oczywiste, że istnieją różne indywidualne drogi do świętości, wymagające prawdziwej pedagogiki świętości, która zdolna jest dostosować się do rytmu poszczególnych osób. Winna ona łączyć całe bogactwo propozycji dostępnych dla wszystkich $z$ tradycyjnymi formami pomocy indywidualnej i grupowej oraz z nowszymi formami udostępnianymi przez stowarzyszenia i ruchy uznane przez Kościóí $^{78}$.

\section{B. ŹRÓDEA I ŚRODKI UŚWIĘCANIA}

Dokumenty kościelne wyraźnie wskazują i opisują zbiór środków służących uświęcaniu. Należą do niego: słowo Boże, liturgia oraz święta służba wszystkich chrześcijan według ich powołania, zwłaszcza pasterzy.

Uświęcanie przez głoszenie i przyjmowanie Słowa Bożego zostało opisane w taki sposób:

Tak wielka zaś tkwi w słowie Bożym moc i potęga, że jest ono dla Kościoła podporą i siłą żywotną, a dla synów Kościoła utwierdzeniem wiary, pokarmem duszy oraz źródłem czystym życia duchowego ${ }^{79}$.

Uświęcanie, jakie niesie liturgia, dokumenty Kościoła przedstawiają za pomocą następujących słów:

Por. Jan Paweł II, List Apostolski Novo millennio ineunte, 30.

78 Tamże, 31.

${ }^{79} \mathrm{KO} 21$. 
Z liturgii przeto, a głównie z Eucharystii jako ze źródła, spływa na nas łaska i z największą skutecznością przez nią dokonuje się uświęcenie człowieka w Chrystusie i uwielbienie Boga, które jest celem wszystkich innych dzieł Kościoła ${ }^{80}$.

Uświęcającą moc posługi urzędów zobrazowano natomiast w zaleceniu:

Wyposażeni bowiem we władzę świętą szafarze służą braciom prawdziwie godnością chrześcijańską, zdążając w sposób wolny, a zarazem według przepisanego porządku do tego samego celu, aby osiągnęli zbawienie ${ }^{81}$.

Jedyne i nieodwołalne wezwanie do świętości wszystkich chrześcijan realizuje się w różnych powołaniach życiowych. Dotyczy to zarówno pasterzy (biskupów, kapłanów i diakonów), jak i ludzi świeckich żyjących w małżeństwach czy rodzinach, podejmujących określone zawody czy też dźwigających ciężar życia jako osoby cierpiące, owdowiałe, ubogie czy prześladowane dla sprawiedliwości ${ }^{82}$. Szczególne świadectwo o powołaniu do świętości uwidacznia się w życiu ludzi żyjących ślubowanymi radami ewangelicznymi. Ich oddanie Bogu i Kościołowi, które nienaruszalnie należy do jego życia i świętości ${ }^{83}$, jest jasnym znakiem pielgrzymiego charakteru egzystencji chrześcijańskiej i pewności nadziei dóbr niebieskich, już zapoczątkowanych w ich życiu ${ }^{84}$. Nauka o powszechnym powołaniu do świętości, zarysowana podczas Vaticanum II, jest nieustannie wzbogacana o kolejne doświadczenia zebrań synodalnych i rozwijana w wydawanych dokumentach Kościoła według wymogów przeżywanych czasów ${ }^{85}$.

Wspomniany już Nadzwyczajny Synod Biskupów w Rzymie w 1985 r., wskazał na prawdę o powszechnym powołaniu do świętości wszystkich wiernych i uświęcającej misji Kościoła:

Ponieważ Kościól jest misterium w Chrystusie, powinien być uważany za znak i narzędzie świętości. $Z$ tego powodu Sobór uczył o powołaniu wszystkich wiernych do świętości

${ }^{80} \mathrm{KO} 10$.

81 KK 18.

82 Por. KK 41.

83 Por. KK 44.

${ }^{84}$ Por. KK 41; Sobór Watykański II, Dekret o o przystosowanej odnowie życia zakonnego; Jan Paweł II, Vita consecrata. Posynodalna adhortacja o życiu konsekrowanym i jego misji w Kościele i śriecie (1996).

85 Por. Jan Paweł II, Adhortacja Familiaris consortio (1981); List apostolski Do mtodych catego świata (1985); Adhortacja Redemptionis donum. O konsekracji zakonnej w świetle tajemnicy Odkupienia (1984); Adhortacja Christifideles laici (1988). Szczególnym znakiem troski o uświęcenie są coroczne listy papieża do kapłanów na Wielki Czwartek. 
(por. KK V). Powołanie do świętości jest zaproszeniem do wewnętrznej przemiany serca i do uczestnictwa w życiu Boga w Trójcy jedynego, co oznacza i przewyższa spełnienie wszystkich pragnień człowieka. Właśnie w tym czasie, kiedy tak wielu ludzi doświadcza wewnętrznej pustki i kryzysu duchowego, Kościół powinien podsuwać i rozwijać wyczucie pokuty, modlitwy, adoracji, ofiary, daru z samego siebie, miłości i sprawiedliwości ${ }^{86}$.

Powołując się następnie na rolę świętych, instytutów życia konsekrowanego, ruchów apostolskich i odnowy duchowej oraz wierność świeckich powołaniu chrześcijańskiemu, Synod w swoich zaleceniach do pasterzy Kościoła przypomniał, że ich pierwszym zadaniem jest wyróżnianie się w świadectwie świętości, by w połączeniu $\mathrm{z}$ odpowiednią formacją intelektualną mogli służyć właściwą pomocą w sprawach dotyczących życia duchowego, zwłaszcza w odnowie zakonów, wspieraniu rozwoju duchowości świeckich,

a w tym przede wszystkim duchowości zakorzenionej w sakramencie małżeństwa i mającej ogromne znaczenie $\mathrm{w}$ dziele przekazywania wiary przyszłym pokoleniom ${ }^{87}$.

\section{CHARYZMATY I RUCHY}

W Kościele, począwszy od jego początków, znaczącą rolę odgrywali charyzmatycy, wierni obdarzeni specjalnymi łaskami w głoszeniu apostolskim, uzdrawianiu, modlitwie czy też w kierowaniu wspólnotą (np. 1 Kor 12 i 14). Ich rola, pomniejszona w następnych wiekach, przejawiała się jednak zwłaszcza w różnorodności powołań zakonnych. Swoją zbawienną rolę dla odnowy Kościoła odegrali choćby założyciele zakonów żebraczych czy ciągle aktualnych dzieł pokutnych (święci Franciszek, Dominik, Filip Nereusz, itp.). Także okres po Soborze Watykańskim II $^{88}$ jest naznaczony wielkim przebudzeniem różnych form grup modlitewno-formacyjnych. Obecnie inicjatywy te odgrywają znaczącą rolę w podejmowaniu nowej ewangelizacji zarówno w wielkich aglomeracjach miejskich w USA, jak i w slumsach miejskich Ameryki Południowej, Afryki czy Azji. $\mathrm{Na}$ uwagę zasługuje też rola ruchów odnowy w działalności ekumenicznej, zwłaszcza gdy się zauważy ich znaczenie w wielu Kościołach niekatolickich. Nowe ruchy apostolskie cechuje poszukiwanie pogłębionego, duchowego wykształcenia przy jednoczesnym podjęciu ważnych zadań społecznych.

\footnotetext{
86 Nadzwyczajny synod biskupów, Relacja końcowa. Dwudziestolecie Soboru watykańskiego II, Wrocław 1986, s. 16.

87 Tamże, s. 18.

88 Por. KK 12.
} 
$\mathrm{Na}$ pierwszym miejscu - jeśli chcemy wymienić ruchy polskie - należy wskazać ruch „Światło-Życie”, który w latach 60-tych został założony przez Sługę Bożego, ks. prof. Franciszka Blachnickiego. Stał się on przykładem owocnej recepcji nauki Vaticanum $I^{89}$.

Drugim ważnym krajowym ruchem świeckich była „Rodzina Rodzin”, powołana do życia w 1952 r. z inspiracji kard. Stefana Wyszyńskiego. Stanowiła ona środowisko wychowania rodziny w duchu zawierzenia Matce Bożej i służby Kościołowi. Także nowy ruch „Cywilizacja Miłości” uchodzi za lokalny w polskim Kościele ${ }^{90}$.

Pod koniec lat 70-tych pojawiło się w Polsce wiele ruchów apostolskich, które utworzyły się na Zachodzie w czasie Drugiego Soboru Watykańskiego. Wniosły one ze sobą wielką radość wiary, opierającą się na soborowej idei odnowionego rozumienia Kościoła. Do tych wspólnot można przykładowo zaliczyć „Odnowę w Duchu Świętym“, „Neokatechumenat” czy „Focolari”. Uwadze nie powinna ujść także znacząca rola duszpasterstwa akademickiego w miastach uniwersyteckich. W latach 80-tych powstał na gruncie polskim ruch „Rodzin Nazaretańskich“, który został założony przez ks. Tadeusza Dajczera ${ }^{91}$.

Aktualnie mówi się o ponad 300 nowych ruchach, społecznościach, wspólnotach i grupach. $5 \%$ wszystkich Polaków, tj. ok. 1,6 miliona, a więc $10 \%$ wszystkich wiernych regularnie chodzących do Kościoła, deklaruje swoją do nich przynależność ${ }^{22}$.

Jednak najbardziej specyficznym polskim fenomenem są bez wątpienia piesze pielgrzymki. Jedynym w swoim rodzaju i bardzo wiele obiecującym jest olbrzymi udział młodych w tych rekolekcjach w drodze. W 1999 r. odbyło się 359 pieszych pielgrzymek do Częstochowy. Wzięło w nich udział prawie 200 tysięcy osób, wśród których było 2000 księży. Są to dane odnoszące się tylko do jednego maryjnego sanktuarium w Polsce ${ }^{93}$.

\section{ZNAMIĘ ŚWIĘTOŚCI W EKUMENII}

W dialogu ekumenicznym podkreśla się potrzebę nawrócenia wszystkich chrześcijan przez uznanie indywidualnych i społecznych grzechów oraz naśla-

89 Por. A. Napiórkowski, O eklezjalno-sakramentalny wymiar stowarzyszeń i ruchów kościelnych, „Sosnowieckie Studia Teologiczne” IV/1999, s. 174.

90 Por. tamże.

91 Por. tamże, s. 175.

92 Por. A. Napiórkowski, Znaki ekumenicznej nadziei,„Via Consecrata” 3 (2000) nr 18, s. 3637; M. Przeciszewski, Kościót w Polsce w epoce wolności, „Wiadomości KAI” (Kościół 2001. Wydanie specjalne 2001), s. 35-36.

93 Por. J. Tomziński, Jasnogórskie Sanktuarium w 1999 roku, „Jasna Góra” 2(2000), s. 31. 
dowanie Jezusa Chrystusa jako fundamentu zbliżenia pomiędzy poszczególnymi wyznaniami ${ }^{94}$.

Dla Kościołów prawosławnych znamię świętości jawi się jako pierwsze i najważniejsze. Pojęcie „przebóstwienia” człowieka Duchem Świętym i jego łączność z tajemnicą wspólnoty Trójcy Świętej jest szczególnym wyznacznikiem posługi Kościoła. Prawosławie wypracowało w swojej tradycji, teologii i praktyce wielkie bogactwo środków uświęcania. Kult tego daru Boga, cześć oddawana świętym w powiązaniu z Eucharystią i całą liturgią świadczy o tym dobitnie.

W pismach i katechizmach chrześcijan pochodzących z reformacji jasno uwidacznia się twierdzenie dotyczące świętości Kościoła, ponieważ jest on przestrzenią uwidaczniającą moc Bożego Ducha działającego w sercach ludzi. Kiedy człowiek ją przyjmuje, „usprawiedliwiony” i odnowiony, tworzy „wspólnotę świętych”. W tym stwierdzeniu bliżej określono, co należy rozumieć pod pojęciem Kościoła ${ }^{95}$.

Podobne przekonanie o świętości Kościoła znajduje się we wspólnym dokumencie ekumenicznym wspólnot chrześcijańskich z $1991 \mathrm{r}$.:

Duch Święty mieszka w świętym Kościele. Kościól ten, który jest święty i uświęca przez słowo i sakramenty, otrzymał od Boga najszczególniejsze powołanie. Świętość Kościoła świadczy o wierności Boga wobec swojego ludu: bramy piekła nie zwyciężą go. Nawet w najciemniejszych czasach historii Kościoła Chrystus usprawiedliwia i uświęca nadal tych, którzy pozostają wierni, tak że Kościół sam jest zdolny w tych czasach wykonywać swoją posługę dla zbawienia ludzkości ${ }^{96}$.

\section{Katolicki (powszechny)}

Znamię to we współczesnym użyciu przez chrześcijan oddawane jest za pomocą wielu terminów, które nie są jednoznaczne i nie tłumaczą się nawzajem. Pod pojęciem „katolicki” rozumie się terminy: powszechny (często zawężony horyzontalnie czy socjologicznie), ogólny, chrystusowy, ogólno-chrystusowy, rzymskokatolicki czy też ekumeniczny ${ }^{97}$. Ta wielość znaczeniowa jest odbiciem

\footnotetext{
94 Por. H. Schütte, Kirche im ökumenischen Verständnis, Paderborn 1991, s. 108.

95 Por. Evangelischer Erwachsenenkatechismus, Gütersloh ${ }^{2} 1989$, s. 903n., za: H. Schütte, Kirche im ökumenischen Verständnis, dz. cyt., s. 104.

96 Confessing the One Faith, 1991, 239, za: H. Schütte, Kirche im ökumenischen Verständnis, dz. cyt., s. 103.

97 Por. H. Schütte, Kirche im ökumenischen Verständnis, dz. cyt., 109.
} 
rozłamów i napięć w Kościele Jezusa Chrystusa. Dla pełniejszego zrozumienia tego znamienia potrzebne staje się zatem najpierw wyjaśnienie terminologiczne, oparte na fundamencie biblijnym. Następnie zaś będą podjęte kwestie związane z przynależnością do Kościoła, a także jego rola w pośrednictwie zbawczym.

\section{Treść pojęcia}

Przymiotnik „katolicki” pochodzi od greckiego terminu kath’holon, tłumaczony jest za pomocą słów: „cały”, „wszechobejmujący” czy „,uniwersalny”i używany zamiennie z określeniem: „powszechny”. Sformułowanie użyte w wyznaniu wiary („wierzę... Kościół katolicki”) ma znaczenie jakościowe i wskazuje na jego pełnię i doskonałość, której fundamentem jest obecność Jezusa Chrystusa, jak to wyraził św. Ignacy Antiocheński: „Gdzie pojawi się biskup, tam niech będzie wspólnota tak, jak gdzie jest Chrystus Jezus, tam i Kościół powszechny" ${ }^{\prime 8}$. Obecność ta daje Kościołowi, jako Ciału Chrystusa zjednoczonemu ze swoją Głową, pełny zakres działania łaski Zbawiciela (por. Ef 1, 22-23). Z tego zjednoczenia Kościół

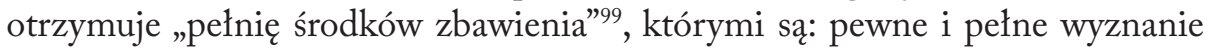
wiary, integralne życie sakramentalne i posługa święceń w sukcesji apostolskiej ${ }^{100}$. W znaczeniu apologetyczno-prawnym w znamieniu „katolickości” Kościoła uwypukla się jego historycznie i geograficznie nieograniczone rozprzestrzenianie, misja. Ma to swoje źródło w posłaniu przez Chrystusa do całego rodzaju ludzkiego (por. Mt 28, 19), co przypomniał Sobór Watykański II:

Do nowego Ludu Bożego powołani są wszyscy ludzie. Toteż Lud ten, pozostając ciągle jednym i jedynym, winien się rozszerzać na cały świat i przez wszystkie wieki, aby spełnił się zamiar woli Boga, który naturę ludzką stworzył na początku jedną i synów swoich, którzy byli rozproszeni, postanowił w końcu w jedno zgromadzić... To znamię powszechności, które zdobi Lud Boży, jest darem samego Pana; dzięki temu darowi Kościół katolicki skutecznie i ustawicznie dąży do zespolenia z powrotem całej ludzkości wraz ze wszystkimi jej dobrami z Chrystusem-Głową w jedności Ducha Jego ${ }^{101}$.

Katolickość, czyli powszechność Kościoła, oznacza więc, że: posiada on pełnię środków zbawienia, służb i stanów; jest posłany do wszystkich ludzi wszystkich czasów oraz nie zależy od miejsca ani czasu ${ }^{102}$. Stanowi zatem jego podstawową

\footnotetext{
98 List do Kościota w Smyrnie, VIII, 2, [w:] Pierwsi świadkowie, dz. cyt., s. 173.

99 DM 6.

100 Por. KKK 830.

101 KK 13.

102 Por. KK 13.
} 
właściwość, w której historyczna obecność i pośrednictwo wszystko ogarniającej Bożej woli zbawienia w Jezusie Chrystusie jest jego zadaniem ${ }^{103}$. W Kościele zachodnim termin „katolicki” uzupełnia określenie „rzymski” dla podkreślenia znaczenia i posługi biskupa Rzymu, którą stanowi jego szczególna troska o prawdziwą jedność Kościoła ${ }^{104}$.

\section{Refleksja biblijno-historyczna}

\section{A. W STARYM TESTAMENCIE}

Historia biblijna poświadcza istnienie dwóch faz rozwoju ludzkości. Najpierw, jako skutek grzechu Adama, uwidacznia się wielkie jej rozproszenie, którego znakiem jest Wieża Babel (por. Rdz 11, 1nn). W powołaniu Abrahama zaczyna się przygotowanie gromadzenia wszystkich narodów świata w jednym królestwie, gdzie przywrócone zostanie pełne panowanie Boga, co zawiera obietnica dana Abrahamowi: „Przez ciebie będą otrzymywały błogosławieństwo ludy całej ziemi” ( $\operatorname{Rdz} 12,3)$. I choć nastąpiło zacieśnienie wybrania i królowania Boga do jednego narodu, to nie zanikła myśl o misji Izraela wobec narodów całego świata. Izrael był świadom, że Bóg króluje odwiecznie (por. Wj 15, 9), na niebie (por. Ps 11, 4; 103, 19), na ziemi (por. Ps 47, 3), w całym wszechświecie rzeczy stworzonych (por. Ps 93, 1n; 95, 3nn), jak też nad wszystkimi narodami (por. Jr 10, 7. 10). Przyjęcie Bożego panowania przez Izraela miało być przykładem wezwania do poznania imienia Pana (por. $1 \mathrm{Krl}$ 8, 43).

Idea uniwersalnego królestwa Bożego najmocniej zaznaczyła się u proroków, zwłaszcza u Izajasza:

Stanie się na końcu czasów, że góra świątyni Pańskiej stanie mocno na wierzchołku gór [...] i popłyną do niej wszystkie narody, mnogie ludy tam się udadzą [...], bo Prawo wyjdzie z Syjonu i słowo Pańskie z Jeruzalem” (Iz 2, 2-3). Uniwersalizm ten objawił się w misji Sługi Jahwe, który ma być światłem dla pogan, niosąc zbawienie aż na krańce ziemi (por. Iz 49,6). Podjęte przezeń dzieło, zwłaszcza Jego poniżenie i ekspiacyjna śmierć, na widok której mnogie narody i królowie się zdumieją, przyniesie wybawienie nie tylko Izraelowi (por. Iz 52, 13-53, 1-12). Przez pełne oczyszczenie Syjonu, które ma być znakiem Bożego królowania, „wszystkie krańce ziemi zobaczą zbawienie Boga naszego (Iz 52, 10).

103 Por. S. Wiedenhofer, Ekklesiologie, [w:] Handbuch der Dogmatik, t. 2, dz. cyt., s. 126.

104 Por. KK 22; także: J. Ratzinger, Primat, [w:] Lexikon für Theologie und Kirche, t. 8, Freiburg-Basel-Rom-Wien 2000, k. 763. 


\section{B. W NAUCE JEZUSA CHRYSTUSA I PIERWOTNYM KOŚCIELE}

Królestwo Boże zajmuje naczelne miejsce w nauce i dziele Jezusa Chrystusa, co zostało wyrażone w pierwszym Jego wezwaniu: „Czas się wypełnił i bliskie jest królestwo Boże. Nawracajcie się i wierzcie w Ewangelię" (Mk 1, 15). Świadkowie Jego działalności zanotowali, że obchodził „całą Galilę̧”, aby przez nauczanie i cuda świadczyć o bliskości nadchodzącego królowania Boga. Jezus nawiązywał do zastanych myśli o królestwie Bożym mającym zapanować w Izraelu. Zdecydowanie jednak przeciwstawiał się wszelkim podziałom i separatyzmom tak narodowym, jak też stanowym czy klasowym. Wszyscy moga mieć udział w obietnicy danej Abrahamowi, a kluczem do bram tego królestwa nie jest przynależność do jednego narodu, ale nawrócenie, wewnętrzna przemiana i wiara w Ewangelię.

Jezus wysyła Dwunastu, aby w Jego mocy i na Jego wzór przepowiadali dobrą nowinę o bliskości królestwa niebieskiego (por. Mt 10, 7). W nich przybierze ono oblicze ziemskie, kształt Kościoła zbudowanego na Piotrze, który otrzymuje klucze królestwa niebieskiego (Mt 16, 18). Właśnie Kościół po wniebowstąpieniu Jezusa będzie świadczył o tym królestwie (por. Dz 1, 8; $\mathrm{J}$ 15, 27), aż do jego wypełnienia się w chwale przy drugim przyjściu Pana (por. Łk 21, 31).

\section{POJĘCIE UNIWERSALNOŚCI KATOLICKIEJ W KOŚCIELE APOSTOLSKIM}

O tym, iż pełnia zbawienia w Jezusie jest dla wszystkich, a nie tylko dla $\dot{Z}_{\text {- }}$ dów, zaświadczył Piotr przez głoszenie Ewangelii poganinowi Korneliuszowi i całemu jego domowi, któremu też, upewniony zesłaniem Ducha Świętego, udzielił chrztu (por. Dz 10, 44-48). Przekonanie o uniwersalnej misji Kościoła zostało potwierdzone na tzw. soborze w Jerozolimie, w następstwie czego ważność misji do pogan została zrównana z misją pośród Żydów (por. Dz 15). Już w pierwszym pokoleniu apostolskim drogi ewangelizacji chrześcijańskiej skierowały się do Samarii, Antiochii, Azji Mniejszej, Grecji, Egiptu, Mezopotamii (Indii), Cypru i Italii. Wielkim świadkiem, a zarazem wykonawcą tego uniwersalnego posłania Kościoła stał się św. Paweł, nazwany Apostołem Narodów: „Nie wstydzę się Ewangelii, jest ona bowiem mocą Bożą ku zbawieniu dla każdego wierzącego, najpierw dla Żyda, potem dla Greka" (Rz 1, 16). Przez przyjęcie Ewangelii wszyscy zostają usprawiedliwieni i, zgodnie z obietnicą, zyskują miano potomstwa Abrahama (por. Ga 3, 26-29).

Najstarsze źródła chrześcijańskie poświadczają przekonanie o powszechności Kościoła: 
Jak ten łamany Chleb rozsiany był po górach, a zebrany stał się czymś jednym, tak niech się zbierze Kościół Twój z krańców ziemi w jedno królestwo Twoje (...) Zbierz, Panie, Kościół od czterech wiatrów w jedno Twoje królestwo ${ }^{105}$.

Przekonanie o katolickości, czyli powszechnej uniwersalności zbawienia dla wszystkich ludów wszystkich czasów, wyzwala w Kościele prawdziwego ducha misyjnego, który korygując wszelkie partykularne i nacjonalistyczno-mesjanistyczne zawężenia, przez usilne głoszenie, świadectwo, dialog i nadzieję rozszerza nieustannie panowanie królestwa Bożego w sercach ludzi.

\section{Wybrane problemy zwiq̨zane z powszechnością Kościoła}

Do najczęściej poruszanych spraw związanych ze znamieniem powszechności należy odnowienie świadomości misyjnej, relacja pomiędzy Kościołem powszechnym a Kościołami partykularnymi, ekumenia, przynależność do Kościoła i jego zbawcze pośrednictwo.

\section{A. OdNOWIENiE ŚWIAdomości Misyjnej KoŚCIOŁA}

Misyjność jest rozumiana w znaczeniu szerszym jako ogólne posłanie Kościoła, a w znaczeniu węższym jako konkretny sposób przeprowadzania ewangelizacji. W sensie teologicznym oznacza udzielanie się miłości trójjedynego Boga, a w sensie historycznym stanowi realizację posłania Jezusa Chrystusa przez apostołów i ich następców pośród wszystkich ludów wszystkich czasów:

Kościół, posłany przez Boga do narodów, aby był powszechnym sakramentem zbawienia, usiłuje głosić Ewangelię wszystkim ludziom z najgłębszej potrzeby własnej katolickości oraz z nakazu swego założyciela”, który powiedział: „Idźcie więc i nauczajcie wszystkie narody, udzielając im chrztu w imię Ojca i Syna, i Ducha Świętego. Uczcie je zachowywać wszystko, co wam przykazałem. A oto Ja jestem z wami przez wszystkie dni aż do skończenia świata" (Mt 28, 18-20) ${ }^{106}$.

Zadaniem posłania misyjnego jest urzeczywistnianie uniwersalności Kościoła. Dlatego w realizacji musi ono być uwolnione od zbyt abstrakcyjnych czy też zawężonych wzorów przekazu Ewangelii, które misjonarze mogą brać z Kościołów swego pochodzenia czy aktualnie dominującej kultury. Historyczne formy pośrednictwa Bożego Objawienia ulegają nieustannej zmianie, wspomagane coraz

105 Nauka dwunastu apostotów, 9, [w:] ALP, t. 1, s. 19.

106 DM 1. 
nowszymi możliwościami cywilizacyjnymi. W odnowionej teologii misji i w jej praktycznej realizacji należy czerpać z soborowej nauki o przynależności do Kościoła powszechnego, odczytać jego stosunek do religii niechrześcijańskich i ich status teologiczny. Przy uznaniu wartości płynących z wymiany międzykulturowej, wzrastającego zrozumienia dialogu, jak też wspólnych dzieł duchowo-socjalnych chrześcijan z niechrześcijanami, misja ad gentes nie straciła nic ze swej aktualności ${ }^{107}$. Wspomniane wyżej środki spotkań i kontaktów mogą ją uczynić bardziej skuteczną i przekonywającą ${ }^{108}$.

\section{B. KOŚCIÓ£ POWSZECHNY A KOŚCIOŁY PARTYKULARNE}

Kościół katolicki, jako jedyna i powszechna wspólnota uczniów Pana (por. Mt 16, 18; 1 Kor 12, 28), uobecnia się i działa w istniejących od czasów apostolskich Kościołach partykularnych. Są one, jak naucza Sobór Watykański II, ukształtowane „na obraz Kościoła powszechnego” ${ }^{109}$. Kościół partykularny, zwany diecezją lub eparchią, jest wspólnotą wiernych chrześcijan związanych jednością wiary i sakramentów, zbierających się wokół swego biskupa jako następcy apostołów. Tak to formułuje Vaticanum II:

Kościół Chrystusowy jest prawdziwie obecny we wszystkich prawowitych miejscowych zrzeszeniach wiernych, które trwając przy swoich pasterzach, same również nazywane są Kościołami... W nich głoszenie Ewangelii Chrystusowej zgromadza wiernych i w nich sprawowana jest tajemnica Wieczerzy Pańskiej... W tych wspólnotach, choć nieraz są one szczupłe i ubogie albo żyją w rozproszeniu, obecny jest Chrystus, którego mocą zgromadza się jeden, święty, katolicki i apostolski Kościół ${ }^{110}$.

Szczególnym znakiem katolickości Kościoła jest praktyczna relacja pomiędzy Kościołem powszechnym a Kościołami partykularnymi, a także więź pomiędzy nimi samymi. Kościól powszechny nie jest ich sumą lub federacją ${ }^{111}$. Nie tworzy

107 Por. Paweł VI, Adhortacja Evangeli nuntiandi (1974); Jan Paweł II, Encyklika Redemptoris missio (1990).

$108 \mathrm{Na}$ osobną uwagę zasługują misyjne pielgrzymki Jana Pawła II, których liczba, zasięg i oddziaływanie postawiły nowe wyzwania całemu Kościołowi, ale także ukazały pełne nadziei perspektywy nowych możliwości ewangelizacyjnych. Nade wszystko w odnowie teologii i świadomości misyjnej pomocą staje się nauczanie papieża wygłaszane w różnych miejscach świata, w tym encyklika Redemptoris missio (1990), według której misja Kościoła przeżywa swój kolejny początek.

109 KK 23; por. DM 20.

110 KK 13.

111 Por. Paweł VI, Adhortacja Evangelii nuntiandi, 62. 
też jedności tylko na poziomie widzialnym i instytucjonalnym. Za błędne też należy uznać twierdzenie, że każdy Kościół partykularny jest w sobie kompletnym podmiotem, a Kościól powszechny powstaje z wzajemnego uznania się wspólnot partykularnych ${ }^{112}$. Jako Ciało Kościołów ${ }^{113}$ lub Komunia Kościołów w swej tajemnicy jest on rzeczywistością ontologicznie i czasowo uprzednią w stosunku do każdego pojedynczego Kościoła partykularnego. Ma to swój wyraz w nazwaniu Kościoła „Matką”, rodzącą Kościoły partykularne jako córki. Objawiło się to w dniu zesłania Ducha Świętego, kiedy we wspólnocie zebranych wokól Maryi i dwunastu apostołów, stu dwudziestu przedstawicieli jedynego Kościoła i przyszłych założycieli wspólnot lokalnych, którym została powierzona misja wobec świata, Kościół mówił już wszystkimi językami ${ }^{114}$ :

Z tego Kościoła, który narodził się i został objawiony jako powszechny, wzięły początek różne Kościoły lokalne jako poszczególne realizacje jednego i jedynego Kościoła Jezusa Chrystusa. Rodząc się wi z Kościoła powszechnego, w nim i z niego czerpią swoją eklezjalność. Dlatego wyrażenie Soboru Watykańskiego II: Kościót w Kościotach i z Kościotórw (Ecclesia in et ex Ecclesiis) jest nieodłączne od drugiego: Kościoty w Kościele $i$ z Kościota ${ }^{115}$.

Znakjedności pomiędzy Kościołami lokalnymi a powszechnym urzeczywistnia się przez ich jedność z Kościołem rzymskim, „który przewodniczy w miłości”"116.

Dlatego z tym Kościołem, na mocy jego wyjątkowego pierwszeństwa, musiały zawsze zgadzać się w sposób konieczny wszystkie Kościoły, to znaczy wierni całego świata ${ }^{117}$.

Wyraził to jeszcze dobitniej św. Maksym Wyznawca:

112 Takie ujmowanie Kościoła oznaczałoby redukcję nie tylko Kościoła powszechnego, ale też i partykularnego. A dzieje Kościoła potwierdzają fakt, ze kiedy jeden z Kościołów partykularnych dążył do samowystarczalności, osłabiając swoją rzeczywistą więź z Kościołem powszechnym oraz z jego żywym i widzialnym centrum, zagrożona stawała się także jego jedność wewnętrzna. Wyizolowany Kościół partykularny, bez wystarczającej łączności z Kościołem powszechnym, stawał samotnie w wobec niebezpieczeństwa utraty wolności w obliczu różnych sił chcących go sobie podporządkować i wykorzystać, por. j. w. 64.

113 Por. KK 23.

114 Por. Kongregacja Nauki Wiary, List do biskupów Kościoła katolickiego o niektórych aspektach Kościota pojętego jako komunia, nr 9, [w:] W trosce o petnię wiary. Dokumenty Kongregacji Nauki wiary 1966-1994, Tarnów 1995, s. 395.

115 Tamże, nr 9, s. 395.

116 Św. Ignacy Antiocheński, List do Rzymian, 1, 1, [w:] ALP, t. 1, dz. cyt., s. 24.

117 Św. Ireneusz, Adversus haereses, III, 3, 2, [w:] ALP, t. 1, s. 166-167; por. DS 3057. 
Istotnie, od zstąpienia do nas Słowa, które stało się ciałem, wszystkie Kościoły chrześcijańskie na całym świecie uznały i uznają wielki Kościól, który jest tutaj (w Rzymie), za jedyną podstawę i fundament, ponieważ zgodnie z obietnicą samego Zbawiciela, bramy piekielne nigdy go nie przemoga ${ }^{118}$.

\section{POWSZECHNOŚć KOŚCIOŁA A EKUMENIA}

W Kościołach reformowanych, zwłaszcza w wyznaniu luterańskim, termin „katolicki” jest zastępowany słowem „chrześcijański”. Jednakże w liturgii, szczególnie w ramach postępującego dialogu ekumenicznego, proponuje się zamienne używanie terminów: katolicki, powszechny i chrześcijański ${ }^{119}$. Pod tymi określeniami rozumie się w ogólności fakt przekraczania przez Kościół w swojej misji wszelkich ograniczeń spowodowanych różnicami narodowymi, klasowymi czy też rasowymi, a także związanymi z miejscem i czasem. Ewangelia bowiem zadomawia się w różnorodnych kulturach i jest ważna dla wszystkich ludzi wszystkich czasów.

Dla pełnego rozumienia znamienia „katolickości” stosuje się wyrażenia św. Ignacego Antiocheńskiego, któremu nadaje się rozszerzone brzmienie:

Gdzie jest Jezus Chrystus, tam jest Kościół katolicki, w którym Duch Święty czyni ludzi we wszystkich czasach bez względu na płeć, rasę lub pozycję uczestnikami Chrystusowego życia i zbawienia ${ }^{120}$.

Podkreśla się też misyjną dynamikę Kościoła, który rozszerza się nieustannie na ziemi, nieograniczany ani przez miejsce ani przez czas.

W znaczeniu wewnętrznym, istotowym, znamię „katolickości” oznacza tożsamość Kościoła, mimo rozproszenia na całej ziemi, ponieważ „ma zdrową naukę” (Tt 2, 1; por. Tm 6, 20), identyczną z nauczaniem apostołów, które wiarygodnie przekazuje. Wyrażono tu przekonanie, podkreślane wspólnie zwłaszcza przez anglikanów i luteran, że Kościołowi została przekazana cała prawda Ewangelii. W tym ogólnym sformułowaniu kryje się jednak bardzo wiele różnic w konkretnej interpretacji pojęcia „całej prawdy Ewangelii”. Z jednej strony bowiem w Kościołach niekatolickich, zwłaszcza prawosławnych i starokatolickich, podkreśla się istotne znaczenie wszystkich siedmiu sakramentów, a z drugiej, zwłaszcza we wspólnotach chrześcijańskich pochodzących $\mathrm{z}$ reformacji, panuje w praktyce

118 KKK 834.

119 Por. H. Schütte, Kirche im ökumenischen Verständnis, dz. cyt., s. 109.

120 Confessing the One Faith. Dokument studyjny o wierze i zatożeniu Kościota (1991), [w:] H. Schütte, Kirche im ökumenischen Verständnis, dz. cyt., s. 110-111. 
wielka dowolność interpretacji, połączona nieraz z całkowitym pominięciem sakramentów lub minimalistycznym rozumieniem ich znaczenia.

W określeniu łączności pomiędzy poszczególnymi wspólnotami, jak też związku z Kościołem powszednim, na pierwszy plan wysuwa się moment jednostkowej więzi poszczególnych wiernych z Kościołem powszechnym, jak to przypomina jeden ze wspólnych dokumentów dialogu katolicko-luterańskiego:

Lokalny charakter Kościoła i jego katolickość muszą być nieustannie strzeżone. Przez uczestnictwo we wspólnocie lokalnej mamy bowiem udział w życiu całego Kościoła: wspólnocie lokalnej (szczególnie małym podstawowym wspólnotom, a także Kościołom lokalnym o regionalnym charakterze) bez tej wspólnoty z Kościołem powszechnym, groziłoby niebezpieczeństwo wpadnięcia w getto lub też pod samowolną władzę jednostek ${ }^{121}$.

Pełne więc urzeczywistnienie katolickości Kościoła możliwe jest tylko na drodze ekumenizmu.

Podstawowe znaczenie ma w tym względzie „udział we wspólnym Chlebie i wspólnym Kielichu", który sprawia jedność wiernych wszystkich czasów i wszystkich miejsc. W opracowaniach ekumenicznych pojawiają się też wskazania na konieczność łączności Kościoła lokalnego z innymi Kościołami partykularnymi:

Chrystus, pełen łaski i prawdy, jest obecny na ziemi w katolickim Kościele. W każdym Kościele znajduje się pełnia łaski i prawdy w katolickości, która domaga się wspólnoty wszystkich Kościołów lokalnych i która gwarantując jego identyczność przedstawia istotną jakość jego własnej wspólnoty ${ }^{122}$.

\section{PRZYNALEŻNOŚĆ DO KOŚCIOŁA}

Razem z omawianą powyżej problematyką oraz kościelnym charakterem innych chrześcijan Sobór Watykański II podjął sprawę przynależności do Kościoła, która na różne sposoby była ujmowana od samych jego początków ${ }^{123}$. Największy wpływ na formułowanie nauki na ten temat wywarł św. Augustyn, rozróżniając pomiędzy przynależnością do ciała i do duszy Kościoła. Doskonała (perfectissime) przynależność jest wtedy, gdy ochrzczony przynależy do Kościoła tak przez zewnętrzne powiązania z prawdziwym Kościołem jako instytucją, jak też przez wyznawanie prawdziwej wiary i przyjmowanie tych samych sakramentów.

${ }^{121}$ Tamże, s. 114.

122 Confessing the One Faith, [w:] tamże, s. 114.

${ }_{123}$ Por. M. M. Garjo-Guembe, Gemeinschaft der Heiligen, dz. cyt., s. 127-131. 
Św. Tomasz z Akwinu przejął istotne elementy poglądu św. Augustyna, podkreślając wewnętrzną stronę tej przynależności. Opierając się na prawdzie, że Chrystus jest Głową mistycznego Ciała Kościoła, św. Tomasz rozróżniał pomiędzy przynależnością aktualną a potencjalną. W pierwszej uczestniczą święci w niebie i członkowie Kościoła, którzy są bez grzechu. Grzesznicy natomiast przynależą tylko in potentia, o ile wierzą (per fidem informem). Także i niewierzący są członkami należącymi do Kościoła in potentia, ponieważ zbawienie Jezusa Chrystusa obejmuje całą ludzkość (etsi actu non sint de Ecclesia) ${ }^{124}$. Podkreślając pośredniczącą rolę Kościoła, Akwinata zaznacza, że bycie jego członkiem nie jest tym samym, co bycie członkiem Chrystusa. Ochrzczeni, którzy żyją łaską, są zarówno członkami Kościoła, jak i Chrystusa - oba te aspekty powinny być ze sobą nierozdzielnie związane.

Naukę św. Augustyna przejął św. Robert Bellarmin, który zajął się problemem przynależności heretyków do Kościoła. Jego naukę można ująć w twierdzeniu: członkami Kościoła są wszyscy ochrzczeni i tylko oni, ponieważ chrzest jest pojmowany jako brama, przez którą wchodzi się do Kościoła. Encyklika Piusa XII Mystici Corporis (1943) stwierdza, że do członków wspólnoty wiernych w rzeczywistości (reapse) mogą być zaliczeni tylko ci, którzy jako ochrzczeni wyznają prawdziwą wiarę i nie odłączyli się od niej przez złe czyny ani nie zostali wyłączeni przez odpowiedzialnych w Kościele. Dlatego ci, którzy od wiary lub od władzy kościelnej są odłączeni, nie żyją w tym samym Ciele i tym samym Bożym Duchem ${ }^{125}$. Encyklika potwierdza tradycyjne przekonanie, według którego w prawdzie i w rzeczywistości do Kościoła należą tylko ci, którzy stanowią w nim jedno nie tylko przez chrzest, ale także w wierze i posłuszeństwie pasterzom. Przekonanie to oparte jest na identyfikacji jedynego Kościoła Jezusa Chrystusa z Kościołem rzymskokatolickim, co zostało powtórzone w encyklice Humani generis z 1950 r. Dla określenia kościelnej sytuacji niekatolików, w odróżnieniu przysługującemu katolikom reapse (w rzeczywistości), używano pojęcia votum (życzenia), które de facto zrównywało ich z nieochrzczonymi, czyli poganami.

Vaticanum II przez szczególne uwypuklenie znaczenia sakramentu chrztu wskazał na całkowicie różną sytuację, jaka jest między niekatolickimi chrześcijanami a poganami ${ }^{126}$ : chrzest jest wejściem do Kościoła, dlatego wszyscy ochrzczeni-niekatolicy są „w pewnym sensie”, aczkolwiek nie w doskonałej jedności (in quadam communione etsi non perfecta) związani z Kościołem katolickim ${ }^{127}$.

W nauce Vaticanum II na temat przynależności do Kościoła wyraźne jest rozróżnienie pomiędzy katolikami, następnie katechumenami, chrześcijanami

\footnotetext{
124 Por. Suma teologiczna, III, q. 8 a. 3.

125 Por. DS 3802.

126 Por. KK 13.

127 DE 3.
} 
niekatolikami, wierzacymi w Boga i poszukującymi Go. W stosunku do katolików Vaticanum II stwierdza:

Sobór święty zwraca się w pierwszym rzędzie do wiernych katolików. Uczy zaś, opierając się na Piśmie Świętym i Tradycji, że ten pielgrzymujący Kościół konieczny jest do zbawienia. Chrystus bowiem... podkreślając wyraźnie konieczność wiary i chrztu (por. Mk 16, 16; J3, 5), potwierdził równocześnie konieczność Kościoła, do którego ludzie dostają się przez chrzest jak przez bramę. Nie mogliby tedy być zbawieni ludzie, którzy wiedząc, że Kościół założony został przez Boga za pośrednictwem Chrystusa jako konieczny, mimo to nie chcieliby bądź przystąpić do niego, bądź też w nim wytrwać. Do społeczności Kościoła wcieleni są w pełni ci, co mając Ducha Chrystusowego w całości przyjmują przepisy Kościoła i wszystkie ustanowione w nim środki zbawienia i w jego widzialnym organizmie pozostają w łączności z Chrystusem rządzącym Kościołem przez papieża i biskupów, w łączności mianowicie polegającej na więzach wyznania wiary, sakramentów i zwierzchnictwa kościelnego oraz wspólnoty (communio $)^{128}$.

Sobór przestrzega jednak przed połowiczną, zewnętrzną tylko przynależnością do Kościoła:

Nie dostępuje jednak zbawienia, choćby był wcielony do Kościoła, ten, kto nie trwając w miłości, pozostaje wprawdzie w łonie Kościoła „ciałem”, ale nie „sercem” Wszyscy zaś synowie Kościoła pamiętać winni o tym, że swój uprzywilejowany stan zawdzięczają nie własnym zasługom, lecz szczególnej łasce Chrystusa; jeśli zaś z łaską tą nie współdziałają myślą, słowem i uczynkiem, nie tylko zbawieni nie będą, ale surowiej jeszcze będą sądzeni ${ }^{129}$.

Przygotowujący się do chrztu

katechumeni, którzy za sprawą Ducha Świętego z wyraźnej woli swojej pragną być wcieleni do Kościoła, już dzięki temu pragnieniu są z nim w łączności; toteż Matka-Kościół już jak na swoich rozciąga swą miłość i troskę ${ }^{130}$.

Na temat chrześcijan niekatolików Vaticanum II naucza:

Co się zaś tyczy tych ludzi, którzy będąc ochrzczeni noszą zaszczytne imię chrześcijan, ale nie wyznają całej wiary lub nie zachowują jedności wspólnoty (communio)

128 KK 14.

${ }^{129}$ KK 14

${ }^{130}$ KK 14. 
pod zwierzchnictwem Następcy Piotra, to Kościół wie, że jest z nimi związany z licznych powodów ${ }^{131}$.

Chodzi o wspólne umiłowanie Pisma Świętego jako normę wiary i życia, gorliwość religijną związaną z wiarą i miłością Boga w Trójcy Świętej, uznanie Chrystusa, Syna Bożego za jedynego Zbawiciela, przyjmowanie sakramentów. Wiele Kościołów posiada episkopat, sprawuje Eucharystię i czci Maryję Matkę ${ }^{132}$. Na szczególne podkreślenie zasługuje więź Kościoła katolickiego z Kościołami prawosławnymi, która jest tak głęboka, że „niewiele jej brakuje, by osiągnęła pełnię dopuszczającą wspólne celebrowanie Eucharystii Pana”133.

W nauce o członkostwie kościelnym niechrześcijan Vaticanum II formułuje twierdzenie: „Także ci, którzy jeszcze nie przyjęli Ewangelii, w rozmaity sposób przyporządkowani są do Ludu Bożego" 134 . Stopnie tego przyporządkowania wyznacza stosunek Kościoła do narodu izraelskiego, mahometan, wyznawców innych religii i wreszcie wszystkich ludzi dobrej woli. W odniesieniu do Izraela podkreśla się, że jego religia jest objawiona, oparta na Przymierzu z Bogiem i Jego obietnicach, a w tym narodzie według ciała narodził się Chrystus (por. Rz 9, 4-5) ${ }^{135}$. O stosunku do mahometanach, religii, która w świecie dzisiejszym odgrywa liczbowo, kulturowo i gospodarczo znaczącą rolę, Sobór mówi:

Zamysł zbawienia obejmuje również tych, którzy uznają Stworzyciela, wśród nich zaś w pierwszym rzędzie muzułmanów, oni bowiem wyznając, iż zachowują wiarę Abrahama, czczą wraz z nami Boga jedynego i miłosiernego, który sądzić będzie ludzi w dzień ostateczny $^{136}$.

Stosunek swój do wyznawców jednego Boga Vaticanum II konkluduje w słowach:

Ci bowiem, którzy bez własnej winy nie znając Ewangelii Chrystusowej i Kościoła Chrystusowego, szczerym sercem jednak szukają Boga i wolę Jego przez nakaz sumienia poznaną starają się pod wpływem łaski pełnić czynem, mogą osiągnąć wieczne zbawienie $^{137}$.

131 KK 15.

132 Por. KK 15.

133 Paweł VI, Przemówienie (14. 12. 1975); por. DE 13-18.

134 KK 16.

135 Por KK 16; DRN 4.

136 KK 16; por. DRN 3.

137 KK 16. 
Kościół uznaje też pozytywne wartości w innych religiach i postawach ludzi, gdy stwierdza:

Nie odmawia też Opatrzność Boża koniecznej do zbawienia pomocy takim, którzy bez własnej winy w ogóle nie doszli jeszcze do wyraźnego poznania Boga, a usiłują, nie bez łaski Bożej, wieść uczciwe życie. Cokolwiek bowiem znajduje się w nich z dobra i prawdy, Kościół traktuje jako przygotowanie do Ewangelii i jako dane im przez Tego, który każdego człowieka oświeca, aby ostatecznie posiadł życie ${ }^{138}$.

\section{E. „POZA KOŚCIOŁEM NIE MA ZBAWIENIA”}

Bezpośrednio z nauką o przynależności do Kościoła wiąże się problem zbawienia. Temat ten jest bardzo trudny i wymaga zrozumienia zarówno samej idei zbawienia, jak i pośredniczącej roli Kościoła. Sformułowanie św. Pawła, że Bóg pragnie, by wszyscy ludzie zostali zbawieni i doszli do poznania prawdy (por. $1 \mathrm{Tm} 2$, 3; por. Tt 2, 11), było związane przez całe dzieje Kościoła z formułą z czasów Ojców Kościoła (wypracowaną przez św. Cypriana): Extra ecclesiam nulla salus („poza Kościołem nie ma zbawienia”), rozumianą często w sposób wykluczający, tzn. przyjmujący odmowę niechrześcijanom prawa do zbawienia. Takim krańcowym przykładem może być wykluczające twierdzenie ucznia św. Augustyna, św. Fulgencjusza z Ruspe (ok. 525) ${ }^{139}$.

Bez wchodzenia w całą historię problematyki, która obrazuje mentalność wielu ludzi Kościoła na przestrzeni wieków ${ }^{140}$, podstawy doktrynalne tej starożytnej maksymy, można podać w dwóch twierdzeniach opisujących jedyność i wyłączność Kościoła w pośrednictwie zbawienia. Po pierwsze, Chrystus jest jedynym źródłem zbawienia, jedynym pośrednikiem między Bogiem a człowiekiem (por. Dz 4, 11-12; Rz 10, 1-14; Łk 12, 8-10; J 14, 1-6), a po drugie Chrystus przekazał swoją misję zbawienia Kościołowi - tworząc z nim jedno (por. Łk 10, 16; J 3, 5; 13, 20; Mt 18, 17; Mk 16, 16; Ga 1, 8; Tt 3, 10; J 10, 11).

Sobór Watykański II podtrzymał powyższą zasadę, jednak, opierając się na nowej wykładni przynależności do Kościoła, dał tym samym jej nową interpretację. Tak to ujmuje Y. Congar: „Teologia katolicka zachowała formułę poza Kościotem

138 KK 16; por. DRN 2; Adhortacja Evangelii nuntiandi, 53.

139 Który stwierdził: „Nie należy wątpić, że nie tylko wszyscy poganie, ale i wszyscy Żydzi, wszyscy heretycy i schizmatycy, umierający poza Kościołem katolickim, pójdą w ogień wieczny, przygotowany dla Szatana i aniołów jego", De fide ad Petrum, 38, 79; PL 65, 704.

140 Dokładne omówienie problemu podaje Y. Congar, Chrystus i zbawienie świata, Kraków 1968, s. 257-310. 
nie ma zbawienia, ale trzeba przyznać, ze nadaje jej dzisiaj sens inny od tego, jaki nadali jej autorzy, Orygenes i św. Cyprian. [...] nie chodzi już o stosowanie tej formuly do jakiejkolwiek konkretnej osoby, ale o obiektywne stwierdzenie, że Kościół Chrystusowy - i że tylko on jako Kościół Chrystusa - jest upoważniony i uprawniony do niesienia zbawienia Jezusowego wszystkim ludziom. A więc formułę tę należy odtąd traktować jak odpowiedź nie na pytanie: Kto zostanie zbawiony?, ale na pytanie: Kto posiada mandat do sprawowania postugi zbawienia? ?11. $^{14}$

W podsumowaniu można stwierdzić:

Aksjomat o konieczności Kościoła do zbawienia nie jest wypowiedzią o zbawieniu człowieka poza Kościołem, ale o szczególnej istocie i szczególnej funkcji Kościoła w związku historii Boga z człowiekiem. Kościół jest konieczny do zbawienia, po pierwsze, jako znak zbawczej miłości Boga w historii ukazanej w służbie Chrystusa (obiektywna konieczność zbawienia). Upominająca funkcja tej wypowiedzi polega na tym, po drugie, że przez to jest wskazane na szczególną przestrzeń zbawienia, która jest otwarta przez posługę Chrystusa w historii do której wchodzi się w wolności i odpowiedzialności wiary, jeśli się nie chce siebie stracić (subiektywna konieczność zbawienia). Konieczność Kościoła do zbawienie polega, po trzecie, na tym, że w naśladowaniu Tego, który wziął na siebie winę człowieka, przedstawić wspólnotę wierzących, przez których Bóg chce wielu uratować (funkcjonalna konieczność zbawienia). Gdy to zdanie jest rozumiane jako wypowiedź o zbawieniu niekatolików lub niechrześcijan, jest ono fałszywe ${ }^{142}$.

\section{E. Apostolskość}

Treść wyznania wiary: „Wierzę... apostolski Kościół” ma swoją podstawę w pytaniach o początki Kościoła, kontynuację jego tradycji i o fundament jego identyczności. W ciągu historii wzmacniały one wewnątrzkościelne spory, w rozwiązywaniu których odwoływano się do świadectw pierwszych świadków. Apostolat pierwotny spełniał bowiem podstawową, wzorczą rolę w przyjmowaniu Objawienia i w jego przekazywaniu, stąd też jedynie on stał się miarodajnym elementem legitymizującym dalszą historię Kościoła. Niniejszym zostanie przedstawiona treść pojęcia apostolskości, następnie jego uzasadnienie

${ }^{141}$ Tamże, s. 261.

${ }^{142}$ S. Wiedenhoffer, Ekklesiologie, [w:] Handbuch der Dogmatik, t. 2, dz. cyt., s. 131. 
historyczno-teologiczne, a w dalszej kolejności kilka uwag na temat współczesnej problematyki dotyczącej Kościoła w jego wymiarze apostolskim.

\section{Treść pojęcia}

\section{A. ISTOTA ApostolstwA}

Apostolskość jest pojmowana tak treściowo („tradycja apostolska”), jak i strukturalnie („apostolska sukcesja”). Gdy chodzi o rozumienie „tradycji apostolskiej”, podkreśla się w nim, że Kościół zbudowano na jednej, raz na zawsze danej, trwającej i miarodajnej wierze apostołów, przekazywanej przez następców mających z nimi łączność konfesyjną. Gdy chodzi o rozumienie apostolskości Kościoła w sensie „sukcesji”, trzeba tu widzieć zasadę, wedle której ma ona widzialną strukturę, a jej wiążącą treścią jest apostolska tradycja. Strukturalne znaczenie apostolskości Kościoła należy do istotnych zagadnień rozmów ekumenicznych ${ }^{143}$.

Pojęcie: „apostoł”, „apostolski” („posłany”), pochodzące z języka greckiego, oznacza człowieka czy też grupę osób obdarzonych szczególnym zadaniem świadczenia o posyłającym. W tym znaczeniu termin „Kościół apostolski” oznacza jego powiązanie $z$ apostołami Jezusa Chrystusa, na świadectwie których oparta jest wiara i jej dalsze przekazywanie. $Z$ konieczności oparcie i źródło posłania apostołów stanowi misja Jezusa Chrystusa. On sam jest posłany przez Ojca: „Jak Ojciec Mnie posłał, tak i Ja was posyłam”(J 20, 21). Na Niego też, jako A postoła i Arcykapłana, na Jego wierność Ojcu spogląda Kościół i każdy chrześcijanin, by utwierdzić się w swoim wyznaniu (por. Hbr 3,1). Kto przyjmuje Jezusa, przyjmuje samego Ojca, który Go posłał (por. Mt 10, 40; J 13, 20). On też jest jedynym fundamentem posłanego przezeń Kościoła (por. 1 Kor 3, 11). Dzieło apostołów i Kościoła opiera się na tym, co już wcześniej Bóg dokonał w Jezusie Chrystusie. $\mathrm{Na} \mathrm{Nim}$, jako na kamieniu węgielnym, wzrasta i rozwija się przez wieki cała budowla Kościoła i jest przez Niego nieustannie utrzymywana (por. Ef 2, 20) ${ }^{144}$.

Można powiedzieć, że apostolat to pełna mocy służba w imię i na polecenie Chrystusa, a jego podstawą jest jedyny historyczny akt posłania przez Zmartwychwstałego ${ }^{145}$. Zadanie apostoła stanowi u obecniające przepowiadanie Ewangelii, a jego cel to zbieranie Kościoła ugruntowanego na tym jednorazowym historycznym świadectwie. Kościół wszystkich czasów skazany jest na swój początek i wypełnia swą istotę poprzez wierność apostolskiemu

\footnotetext{
${ }^{143}$ Por. W. Kasper, Katholische Kirche, art. cyt., k. 329-330; J. Morawa, Sukcesja apostolska, dz. cyt., s. 1141-1147.

144 H. Schütte, Kirche im ökumenischen Verständnis, dz. cyt., s. 116.

145 Por. S. Wiedenhoffer, Ekklesiologie, [w:] Handbuch der Dogmatik, t. 2, dz. cyt., s. 132.
} 
świadectwu uobecnianemu w przepowiadaniu (martyria), kulcie (leiturgia) i w posłudze wobec świata (diakonia). Związanie Kościoła ze świadectwem apostołów zostało oparte na obietnicy nieustannego działania Ducha Świętego: ponieważ w Kościele działa ten sam Duch, który sprawiał pierwsze świadectwo apostołów, jako wspólnota wierzących ma on pewność, że nie odetnie się od gwarantującego mu identyczność świadectwa apostolskiego. Apostolskość Kościoła oznacza więc także jego identyczność zapewnioną przez działanie Ducha Chrystusowego.

Apostolskość Kościoła jako zobowiązanie i obietnica przysługuje najpierw całemu Kościołowi, czyli wszystkim członkom ludu Bożego w jego podstawowej posłudze, jaką jest przepowiadanie Ewangelii, w służbie Bożej i w konkretnym życiu. Dlatego też, kiedy Kościół podejmuje wysiłek reformy, kieruje apel odnowienia apostolskiej świadomości do wszystkich wierzących. Kiedy natomiast chce ustrzec swoje apostolskie i misjonarskie posłanie, powołuje się na apostołów Jezusa Chrystusa i na ciągłość ich urzędu w sukcesji apostolskiej w posłudze biskupów.

\section{B. APOSTOLSKOŚĆ KOŚCIOŁA}

Kościół jest apostolski w potrójnym sensie, gdyż:

- był, jest i pozostanie oparty na „fundamencie apostołów” (Ef 2, 20; Ap 21, 14), świadkach wybranych i posłanych przez samego Chrystusa ${ }^{146}$;

- strzeże i przekazuje w mocy Ducha Świętego cały depozyt nauki zbawienia, otrzymany od apostołów (por. 2 Tm 1, 13-14);

- jest prowadzony, uświęcany i nauczany - aż do powtórnego przyjścia Pana Jezusa - przez następców w misji apostolskiej, tj. kolegium biskupów, wspomaganych przez kapłanów, w ścisłej jedności „z następcą Piotra, Najwyższym Pasterzem Kościoła" ${ }^{\prime 14}$.

Oprócz biskupów, następców apostołów, istnieją inne specyficzne, instytucjonalne punkty kościelnej apostolskości, które mają ścisły związek z apostołami Pana. Są nimi Pismo Święte i Tradycja, których znaczenie jest bardzo akcentowane przez wszystkie wyznania chrześcijańskie. Apostolskość Kościoła polega bowiem na wzajemnym i różnorodnym powiązaniu funkcji Pisma Świętego, kościelnych reguł i wyznań wiary oraz posługi biskupiej.

\section{BISKUPI JAKO NASTĘPCY APOSTOŁÓW}

Istotnym znakiem apostolskości Kościoła jest sukcesja biskupów. Wyraża się przez nią sakramentalna struktura przekazu wiary i naśladowania: przekaz

\footnotetext{
146 Por. DM 9.
}

147 DM 5. 
odbywa się tutaj w formie osobistego wybrania, posłania i osobistego świadectwa. Przekonanie to, wspólne katolikom, prawosławnym, anglikanom i starokatolikom, oparte jest na następującym dowodzie: Pan Jezus, sam będąc posłanym i wyposażonym przez Ojca w pełnię władzy (por. Hbr 3, 1; Mt 10, 40; J 5, 24. 30; 13, 20), powołał apostołów, których wezwał do naśladowania siebie i przekazał im swoje posłanie (successio sui: por. Mk 3, 13; 1 Kor 15, 3nn; 2 Kor 5, 20; J 17, 18; 202, 21). Świadomi swego posłania apostołowie przekazują je następcom (successio apostolica: por. $\mathrm{Dz} 20,28-32 ; 1 \mathrm{Tm} 4,14 ; 2 \operatorname{Tm} 1,6)$ z poleceniem, aby i oni przez nakładanie rąk czynili tak dalej (por. $1 \mathrm{Tm} 5,22 ; 2 \mathrm{Tm}$ 2, 2; Tt 1, 5).W urzędzie biskupa mocne trwanie przy nauce apostolskiej jest powiązane $z$ naśladowaniem apostoła w przekonywającym świadectwie. Sobór Watykański II tak to określa:

Aby powierzona im [apostołom] misja była kontynuowana po ich śmierci, bezpośrednim swoim współpracownikom przekazali, jak w testamencie, zadanie prowadzenia dalej i umacniania rozpoczętego przez siebie dzieła, zalecając im czuwanie nad całą trzodą, w której Duch Święty ich umieścił, aby byli pasterzami Kościoła Bożego. Ustanowili więc takich mężów, a następnie zarządzili, aby gdy tamci umrą, posługiwanie ich przejęli inni doświadczeni mężowie. Jak więc trwa misja (munus) powierzona przez Pana indywidualnie Piotrowi, pierwszemu z Apostołów, i ma być przekazywana jego następcom, tak trwa apostolska misja pasterzowania w Kościele, aby była nieprzerwanie sprawowana przez święty stan biskupów”. Dlatego Kościół naucza, że „biskupi z ustanowienia Bożego stali się następcami Apostołów jako pasterze Kościoła; kto więc ich słucha, słucha Chrystusa, a kto nimi gardzi, gardzi Chrystusem i Tym, który posłał Chrystusa ${ }^{148}$.

W urzędzie biskupa została zinstytucjonalizowana odpowiedzialność za kontynuację przekazu depozytu wiary i jej kościelna żywotność, a także jej szczególne sakramentalne uobecnienie ${ }^{149}$.

\section{D. ŚWIADOMOŚĆ APOSTOLSTWA}

Z istoty apostolskości Kościoła wypływa świadomość posłania i zadanie kontynuowania, w komunii wiary i życia z jego początkiem, misji wszystkich wierzących w Chrystusa. Chrześcijanie czynią to na różne sposoby, uczestnicząc w tym jednym posłaniu, angażując się, zgodnie ze swoim powołaniem i możliwościami, w budowanie królestwa Chrystusa na całej ziemi przez dobrą nowinę o odkupieniu $^{150}$. Czynią to przez ewangelizację i rozszerzanie Kościoła pośród tych ludów

\footnotetext{
148 KK 20; por. KKK 861-862.

149 Por. S. Wiedenhoffer, Ekklesiologie, [w:] Handbuch der Dogmatik, t. 2, s. 133.

150 Por. DA 2.
} 
i społeczeństw, gdzie on nie zapuścił jeszcze korzeni ${ }^{151}$. Skuteczność tego apostolstwa, zarówno wyświęconych jak i świeckich, którego źródłem i początkiem jest Chrystus, zależy od ich żywego z Nim zjednoczenia (por. J 15, 5) ${ }^{152}$. Duszą wszelkiego apostolstwa jest miłość, czerpana przede wszystkim z Eucharystii. Równocześnie rośnie coraz większe przekonanie, że wobec podziału Kościoła i braku jedności w przekazywanej prawdzie objawionej, chrześcijanie dla większej owocności swego apostolstwa, będą podejmować impulsy płynące z ruchu ekumenicznego. Sam bowiem ekumenizm jest szczególnym znakiem misyjności, wzbudzonym przez Ducha Świętego dla przywracania Kościołowi jego zamierzonej przez Chrystusa jedności opartej na fundamencie apostolskim.

\section{Uzasadnienie historyczno-teologiczne}

Przekonanie, tak mocno podkreślane u katolików i prawosławnych, że obecny charakter ich Kościołów jest identyczny z wiarą i życiem Kościoła apostołów, poddaje się, zwłaszcza w środowiskach pochodzących z Kościołów reformowanych, ostrej krytyce i zdecydowanie się odrzuca. Przykładowo można tu wskazać na myśl teologa reformowanego Emila Brunnera (1889-1966), który opierając się na wywodach Rudolfa Sohma, sformułował pogląd, że istniejący dzisiaj Kościół jest owocem odejścia od apostolskich korzeni, a jego dzieje należy ocenić jako historię dekadencji ${ }^{153}$. Według jego tezy, przyjętej dość powszechnie w kręgach protestanckich, początek Kościoła stanowiła wspólnota wierzących w Chrystusa, pozbawiona jakiejkolwiek organizacji, kierująca się miłością i charyzmatami. Okres odchodzenia od pierwotnego wzoru, zaznaczony w późniejszych pismach Nowego Testamentu, jest scharakteryzowany przez zamianę decyzji wiary jako osobistego spotkania z Jezusem Chrystusem w dogmat, wyparcie miłości przez prawo, a ducha przez urząd. Ta zmiana jest widoczna szczególnie w Kościele rzymskokatolickim, który według Brunnera najdalej odszedł od wzoru pierwotnego Kościoła.

Kontrowersje istnieją także wokól pojmowania urzędu apostolskiego i władzy w Kościele. Nawet jeśli pośród chrześcijan przyjmuje się, że w Kościele założonym przez Jezusa istniał jakiś rodzaj władzy, to nie ma zgodności co do prerogatyw i wzajemnego stosunku Piotra i pozostałych apostołów. Stanowisko przeciwne Kościołowi katolickiemu utrzymuje, że apostołowie otrzymali od Jezusa Chrystusa jedynie posługę słowa i sakramentów, $z$ wykluczeniem władzy rządzenia

151 Por. DM 6.

152 Por. DA 4.

153 Swoje tezy opublikował w książce: Das Missverständnis der Kirche, Stuttgart 1951; por. tenże: Die Lehre von der Kirche, vom Glauben der Vollendung, Dogmatik, Zürich-Stuttgart 1960. 
wiernymi. Pojęcie władzy miałoby pozostawać w sprzeczności z duchem chrześcijaństwa, ponieważ jedynym ojcem jest Ojciec niebieski, jedynym Panem i Nauczycielem Chrystus, wierni zaś są dla siebie braćmi i siostrami (rodzeństwem). Kościół to wspólnota równych, w której Chrystus lub Duch Święty niektórych wiernych przeznaczył do świętej posługi, ale bez prawa sprawowania władzy nad innymi. W Kościele nie ma przełożonych i poddanych.

Powyższe przekonania zmuszają do historyczno-teologicznej analizy pojęcia apostolskości Kościoła, by uwydatnić identyczność Kościoła katolickiego z Kościołem apostolskim, a tym samym jeszcze owocniej podejmować zarówno ekumeniczny dialog, jak i dzieło ewangelizacji świata. Szczególnie istotna jest tutaj sprawa sukcesji Piotra oraz apostolskiej sukcesji biskupów.

\section{A. ROLA PIOTRA W PIERWOTNYM KOŚCIELE I SUKCESJA JEGO URZĘDU}

Podstawowym znakiem zasadniczej roli Piotra w pierwotnym Kościele jest jego rola pierwszego (najważniejszego) świadka zmartwychwstania Jezusa. Świadczy o tym najstarsza tradycja zawierająca formułę głoszącą ukazanie się Chrystusa Piotrowi:

Chrystus [...] ukazał się Kefasowi, a potem Dwunastu. Później zjawił się więcej niż pięciuset braciom [...]. Potem ukazał się Jakubowi, później wszystkim apostołom (1 Kor 15, 3nn).

Wśród egzegetów istnieje powszechna zgoda, że w powyższym wypadku Paweł posłużył się pierwotną formułą kerygmatyczną: według Pisma Chrystus umarł za nasze grzechy, według Pisma został pogrzebany i zmartwychwstał trzeciego dnia, i ukazał się. Jeśli Paweł dodał do tej formuły imiona, zwłaszcza Kefasa, to musiał on mieć ustaloną pozycję w apostolskim przepowiadaniu. Należało to do podstawowych argumentów wiary pierwotnego Kościoła.

O wyjątkowej roli Piotra świadczy jego pozycja we wspólnocie jerozolimskiej, której znaczenie było zakorzenione zarówno w ważności tego miasta dla Żydów na gruncie Objawienia Starego Testamentu, jak też w fakcie, że tam Pan Jezus został ukrzyżowany i zmartwychwstał. Tam też - według Dziejórw Apostolskich i Ewangelii Łukasza i Jana - objawił się zmartwychwstały Chrystus. Nadto przez pierwsze dziesięciolecia istnienia Kościoła Jerozolima była największym skupiskiem chrześcijan.

Opisaną w Dziejach Apostolskich rolę uwypuklają następujące fakty: Piotr znajduje się na czele zgromadzonych w wieczerniku (por. Dz 1, 13); przewodniczy zebraniu uzupełniającemu kolegium Dwunastu przez wybór Macieja (por. 1, 15); osądza Ananiasza i Safirę (por. 5, 1-11); w imieniu całej wspólnoty Wieczernika 
przemawia do zebranych tłumów o wypełnieniu się zapowiedzi obietnic mesjańskich w ukrzyżowanym i zmartwychwstałym Jezusie Chrystusie; jako pierwszy przyjmuje do Kościoła pogan (por. 10-11, 18); w imieniu Jezusa uzdrawia (por. 3, 1-10), wskrzesza umarłego (por. 9, 36-42) i prowadzi zakrojoną na wielką skalę działalność misyjną ${ }^{154}$.

Powyższe summarium roli Piotra, widziane bardziej od strony jego zewnętrznej działalności, prowadzi do pytania o naturę jego przełożeństwa: Czy miało ono charakter uniwersalny, czy tylko lokalny? Czy był to prymat czasowy, czy też trwały? Choć Dzieje Apostolskie oraz listy Pawła jednoznacznie wskazują na wyjątkową rolę Piotra, dopuszczają jednak różnorodną, nawet przeciwstawną interpretację. Protestanci, odrzucający prymat papieża, będą dowodzić, że Piotr był lokalnym zwierzchnikiem gminy w Jerozolimie. Gdy ją opuścił, władzę przejął Jakub. Jednak ani jeden, ani drugi nie sprawował władzy o zasięgu uniwersalnym. Wspomniany początkowy prymat Piotra przeszedł na Jakuba.

Egzegeci katoliccy wskazują natomiast, że Piotr i Jedenastu nie byli nigdy lokalnymi kierownikami gmin, lecz podejmowali działalność z założenia uniwersalną. Lokalni zwierzchnicy (jak Jakub, którego autorytet ze względu na pokrewieństwo z Jezusem obejmował jedynie Kościół jerozolimski) rekrutowali się z coraz liczniejszych wspólnot.

Bezpośrednio z tych rozważań wyłania się kwestia sukcesji urzędu Piotrowego. Należy tu wykazać, że Piotr osobiście miał kontakt z gminą rzymską lub pełnił w niej wyjątkową rolę, a ten prymat przyjęli następujący po nim biskupi Rzymu, których pozycja była ponadto w widoczny sposób uznawana przez inne Kościoły.

Rzymski pobyt Piotra nie był kwestionowany ani w starożytności, ani w średniowieczu. Także w okresie reformacji (poza pojedynczymi głosami) nie podważano tego faktu. Dopiero w XIX wieku krytyka protestancka poczęła kategorycznie zwalczać jego historyczną wiarygodność (np. J. G. von Eickhorn; F. von Schleiermacher; F. Chr. Baur). Jednakże właśnie w łonie protestantyzmu rozpoczęły się dogłębne badania, które potwierdziły rzymską obecność Piotra $^{155}$. Na wiele dowodów o związkach św. Piotra z Rzymem wskazują wykopaliska archeologiczne, prowadzone systematycznie od XVIII w. Mówi się

154 Por. A. Paciorek, Rola Piotra w Kościele pierwotnym, [w:] J. Szlaga (red.), Kościót w świetle Biblii, Lublin 1982, s. 68-71; R. Pesch, Neutestamentliche Grundlagen des Petrusamtes, [w:] K. Lehmann, Das Petrusamt. Geschichtliche Stationen seines Verständnisses und gegenwärtige Positionen, München-Zürich 1982, s. 11-41; J. Gnilka, Der Petrusdienst-Grundlegung im Neuen Testament und Ausprägung in der frühen Kirche, [w:] P. Hünermann, Papstamt und Ökumene. Zum Petrusdienst an der Einheit aller Getauften, Regensburg 1997, s. 9-24.

155 Por. A. Harnack, Die Chronologie der altkirchlichen Literatur bis Eusebius, t. 1, Lepizig 1893 (na str. 244, w przypisie 2 pisze: „Śmierć męczeńska Piotra w Rzymie poczęła być zwalczana przez protestanckie, tendencyjne i krytyczne uprzedzenia”); H. Lietzmann, 
o śladach pierwszego grobu apostołów Piotra i Pawła w kościele św. Sebastiana, stojącego dziś w miejscu domu dawnej dzielnicy żydowskiej, który miał być „domem Piotra”. Najwięcej dowodów dostarczyły wykopaliska pod bazyliką św. Piotra na Watykanie w roku 1939. Ołtarz papieski, czyli Konfesja św. Piotra, był zbudowany nad pomnikiem nagrobnym św. Piotra na wzgórzu watykańskim ${ }^{156}$.

Obecnie przytacza się (także wśród protestantów) dowody najstarszej tradycji, które mówią pośrednio lub wprost o pobycie św. Piotra w Rzymie. Wśród tych świadectw na szczególną uwagę zasługują: List św. Klemensa Rzymskiego, Listy św. Ignacego Antiocheńskiego, a zwłaszcza List do Rzymian ${ }^{157}$, List Dionizego z Koryntu (ok. 170), relacje Gajusa, prezbitera rzymskiego z czasów papieża Zefiryna (198-217), a nade wszystko Adversus haereses św. Ireneusza z Lyonu $(\dagger 202)^{158}$.

To, że biskupi rzymscy od IV-tego wieku posiadali rzeczywisty prymat jurysdykcji nad całym Kościołem, nie podlega dyskusji. Nie tylko Leon Wielki (440-461) i Innocenty I (401-417), ale już Syriusz (384-399) i Damazy (366384) są uznawani przez niekatolickich nawet badaczy za papieży w pełnym znaczeniu tego słowa ${ }^{159}$. Autorytet papiestwa rozwinął się w pełni na soborach powszechnych w Efezie (431) i Chalcedonie (451). W 382 r., jak wynika to z tzw. Decretum Gelasianum, synod rzymski oświadczył:

Chociaż po całym świecie rozproszone katolickie Kościoły są komnatą nowożeńczą Chrystusa, to jednak Kościół Rzymski posiada pierwszeństwo i to nie na skutek decyzji soborów, lecz otrzymał on prymat przez słowa Pana i Zbawiciela: Ty jesteś Piotrem, a na tej skale zbuduję mój Kościół ${ }^{160}$.

Pośród świadectw mówiących o pewnej formie prymacjalnej biskupów Rzymu jest List do Koryntian Klemensa Rzymskiego. Został on napisany z powodu konfliktu, jaki wybuchł we wspólnocie korynckiej około 96 roku. Oto „prezbiterzy o długim prestiżu” zostali „niesprawiedliwie” pozbawieni swego urzędu. Fakt ten

Petrus und Paulus in Rom, Leipzig 1927; F. Heiler, Altchristliche Autonomie und päpstlicher Zentralismus, München 1941.

156 Por. T. Klauser, Die römische Petrustradition, Köln u. Opladen 1956; E. Kirchbaum, Die Gräber der Apostelfürsten, Frankfurt 1957.

157 W liście tym św. Ignacy złożył szczególny hołd Kościołowi w Rzymie jako „przodującemu w miłości”, wstęp [w:] ALP, t. 1, dz. cyt., s. 24.

158 Por. W. Brandmüller, Petrus und seine Nachfolger, [w:] tenże (red.), Mysterium Kirche, Aachen 1996, s. 142n.

159 Por. F. Heiler, Altchristliche Autonomie und päpstlicher Zentralismus, München 1941, s. 203nn. 160 DS 163. 
spowodował podział we wspólnocie. W liście, którego autorem jest biskup, cała wspólnota rzymska kieruje do Koryntu prośbę, by zakończyć konflikt przez przywrócenie legalnych i prawowitych przełożonych: „Gdyby zaś ktoś nie posłuchał tego, co Bóg przez nas mówi, niechże wie, że dopuszcza się grzechu i na wielkie naraża się niebezpieczeństwo" 161 . Choć wspólnota w Koryncie nie znajdowała się w polu oddziaływania lokalnego biskupa Rzymu, interwencja Klemensa została przyjęta $\mathrm{z}$ wielkim respektem.

Inne świadectwo związane jest z postacią papieża Wiktora I (189-199). Chodzi o trwającą kontrowersję w sprawie daty święcenia Wielkanocy. Kościoły Małej Azji obchodziły ją dwa dni po 14 Nisan, natomiast w całym Kościele w pierwszą niedzielę po 14 Nisan. Wiktor I chciał usunąć niejednolitość zwyczaju i zażądał w tym celu od poszczególnych prowincji kościelnych zajęcia stanowiska. W różnych miejscach odbyły się lokalne synody, których równoczesność zdaje się wskazywać na kierowniczą rolę i organizacyjne dyrektywy z Rzymu. Biskupi Palestyny, Pontu, Italii i wielu innych prowincji opowiedzieli się za praktyką Rzymu. Tylko małoazjaci, obradujący pod przewodnictwem Polikratesa, biskupa Efezu, odrzucili rzymskie uregulowanie sprawy. Papież zażądał od Kościołów Małej Azji przyłączenia się do większości, grożąc wyłączeniem ich ze wspólnoty jednego Kościoła. I choć przeciw decyzji Wiktora wystąpił św. Ireneusz z Lyonu, ganił tylko jej szorstkość, ale nie kwestionował prawa papieża do rozstrzygania wspomnianego problemu ${ }^{162}$.

Niezwykle ważnym wskazaniem na rolę biskupa Rzymu jest świadectwo św. Ireneusza z Lyonu, podane w kontekście sukcesji apostolskiej. W trzeciej księdze Adversus haereses pisze on:

Oczywiście zbyt wiele miejsca zajęłoby w niniejszej księdze wyliczanie następujących po sobie hierarchów we wszystkich Kościołach; ograniczę się więc tylko do przedstawienia tradycji apostolskiej oraz nauki wiary, jaka drogą kolejnego następstwa biskupów dotarła do nas w największym, najstarszym, powszechnie znanym Kościele rzymskim, założonym i zorganizowanym przez dwóch najznakomitszych apostołów: Piotra i Pawła [...] Z wymienionym bowiem Kościołem (rzymskim), jako przewyższającym wszystkie inne dostojnością swego apostolskiego pochodzenia, zgadza się na pewno cały Kościół, to jest wszyscy wierni na całym świecie, w sprawie przechowywania tradycji odziedziczonej po apostołach ${ }^{163}$.

161 List do Koryntian, 59 [w: ] ALP, t. 1, dz. cyt., s. 24.

162 Por. J. Daniélou, Od poczattórw do końca trzeciego wieku, [w:] Historia Kościota, t. 1, dz. cyt., s. $95 \mathrm{n}$.

163 Zdemaskowanie i odparcie fatszywej gnozy, (Adversus haereses), 3, [w:] ALP, t. 1, dz. cyt. s. $167-168$. 
Dalej autor podaje listę dwunastu kolejnych następców w ich apostolskim urzędzie w Rzymie, sięgającą do czasów jemu współczesnych, zakończoną stwierdzeniem:

W takim oto porządku, drogą nieprzerwanego następstwa dotarła do nas tradycja apostolska, z czego wynika wyraźnie, że dzisiaj wyznajemy tę samą zbawienną wiarę, jaką Kościół przejął od apostołów i pieczołowicie ją przechowując, przekazał nam w nieskalanej postaci ${ }^{164}$.

Z pożytkiem należałoby dodać także ważny argument $\mathrm{z}$ badań historycznych dotyczących prymatu biskupa Rzymu. W oczach historyka prymat występuje $\mathrm{w}$ formie rozwoju zasianego ziarna, które rozwinęło się w pełni przez pierwsze cztery wieki ${ }^{165}$.

Ostateczną krystalizację świadomości prymacjalnej Kościoła rzymskiego pokazują słowa kazania papieża Leona Wielkiego, wygłoszone podczas uroczystości św. apostołów Piotra i Pawła w 441 roku: „Przez siedzibę Piotra stałeś się, Rzymie, stolicą świata; a przez Boską religię rządzisz bardziej niż kiedykolwiek przez ziemskie panowanie"166.

\section{B. SUKCESJA BISKUPÓW W KOŚCIELE POAPOSTOLSKIM}

Jasno określona rola biskupów jako następców apostołów zaświadczona jest w pismach pozabiblijnych na przełomie I i II wieku, a więc jeszcze w czasie tworzenia się kanonu Nowego Testamentu. Z tego czasu wyróżnia się wspomniane wyżej świadectwo św. Klemensa Rzymskiego, zawarte w jego Liście do Koryntian (ok. 96 r.). Istotą powstałego tam konfliktu było dokonane przez wspólnotę „niesprawiedliwe" pozbawienie urzędu "prezbiterów o długim prestiżu” ${ }^{167}$. Interesujące są tutaj dwa stwierdzenie. Pierwsze odnosi się do sukcesji apostolskiej biskupów:

Ale apostołowie dowiedzieli się także od Pana naszego Jezusa Chrystusa, że kiedyś powstanie spór o godność biskupią. Dlatego, przewidując z góry co się stanie, gdy ustanowili

\footnotetext{
${ }^{164}$ Tamże, 3, s. 168; por. K. Drzymała, Prymat św. Piotra i jego następców w świetle historii i dogmatu, [w:] „Homo Dei. Przegląd ascetyczno-duszpasterski” 112 (1963), z. 2, s. 92.

165 Por. K. Schatz, Papsttum - Ärgernis und Konkretion des Katholischen, [w:] W. Brandmüller (red.), Das eigentlich Katholische, Aachen 1997, s. 231nn.

166 Cyt. za: K. Schatz, Unkonventionelle Gedanken eines Kirchenhistorikes zum päpstlichen Primat, [w:] P. Hünermann, Papstamt und Ökumene, Regensburg 1997, s. 26; por. K. Schatz, Der päpstliche Primat. Seine Geschichte von den Ursprüngen bis zur Gegenwart, dz. cyt., s. 1-55.

167 Klemens używa, podobnie jak św. Paweł, zamiennie pojęć: biskup i prezbiter w odniesieniu do tych samych osób.
} 
wyżej wymienionych biskupów i diakonów, od razu wydali rozporządzenie (ordinationem dederunt), że po śmierci tychże inni wypróbowani Duchem mężowie mają objąć następstwo na ich urzędzie (ministerium) ${ }^{168}$.

Ignacy Antiocheński († ok. 110) jest pierwszym historycznym świadkiem episkopatu monarchicznego: „biskupi (są) ustanawiani aż po krańce (ziemi)”169. Biskup objawia się jako gwarant jedności, liturgii i nauki w Kościele: „Wszyscy mianowicie, którzy są Boży i Jezusa Chrystusa, są z biskupem"170.

Uważajcie za ważną tylko taką Eucharystię, która sprawowana jest pod przewodnictwem biskupa, lub tego, komu on zleci [...]. Nie wolno bez biskupa ani chrzcić, ani sprawować $\operatorname{agapy}^{171}$.

Do urzędów wspólnoty należą: biskup, kolegium prezbiterów jako zgromadzenie doradcze i diakoni ${ }^{172}$.

Ireneusz wskazuje na biskupią sukcesję jako znak kontynuacji nauki apostolskiej w obecnym nauczaniu Kościoła. Centralnym punktem jest tutaj identyczność nauki z przekazem pochodzącym od apostołów. Ta argumentacja zakłada, że biskupi jako nauczyciele Kościoła są znakiem identyczności Kościoła z apostolskim przekazem: $\mathrm{z}$ następstwem biskupstwa zwierzchnicy w Kościele otrzymali „niezawodny charyzmat prawdy” (charisma veritatis acceperunt) ${ }^{173}$. Ireneusz wskazuje także na szczególną rolę Kościołów w Rzymie, Smyrnie i Efezie, które ze względu na ich apostolskie fundamenty są najprzedniejszymi świadkami prawdziwości nauki Kościoła.

Podsumowując, można powiedzieć, że apostolska sukcesja episkopatu jest dla Ireneusza nade wszystko znakiem identyfikującym każdy Kościół w czasie i miejscu z Kościołem Boga, co jest potwierdzone przez sukcesję biskupów. To samo znajduje się u Orygenesa: przekaz nauki wiary łączy wymiar apostolski z kościelnym ${ }^{174}$.

Aby jeszcze mocniej wyrazić rolę biskupów, trzeba zwrócić uwagę na pewną historyczną rzeczywistość: już przy końcu II wieku różnorodne problemy, z którymi borykały się wspólnoty, były rozważane na synodach biskupich, gdzie Kościoły

168 List do Koryntian, 44, [w:] ALP, t. 1, dz. cyt., s. 23.

169 Do Kościota w Efezie, III, 2, [w:] Pierwsi świadkowie, dz. cyt., 134.

170 Do Kościota w Filadelfi, III, 2, [w:] Pierwsi świadkowie, dz. cyt., s. 164.

171 Do Kościota w Smyrnie, VIII, 1. 2, [w:] Pierwsi świadkowie, dz. cyt., s. 173.

172 Por. Do Kościota w Magnezji, VI, 1, [w:] Pierwsi świadkowie, dz. cyt., s. 145.

173 Tamże, IV, 26, 2 [w:] A. Bober (red.), Antologia Patrystyczna, Kraków 1966, s. 50.

174 O zasadach, I, przedmowa, 2, Kraków 1996, s. 52. 
lokalne reprezentowali biskupi, którzy kolegialnie podejmowali rozstrzygnięcia w odniesieniu do życia wspólnot.

\section{Urząd apostolski w Kościele we współczesnej myśli teologicznej}

Współczesna refleksja teologiczna na temat Urzędu Apostolskiego i Urzędu Piotrowego jest zakorzeniona nade wszystko w Konstytucji dogmatycznej o Kościele Lumen gentium Vaticanum II, która podaje naukę o roli episkopatu.

\section{A. KOLEGIUM BISKUPÓW}

Trzeci rozdział Lumen gentium określa w świetle danych skrypturystycznych związki zachodzące pomiędzy apostolstwem i episkopatem. Istnienie episkopatu Konstytucja uzasadnia charakterem powierzonego apostołom ewangelicznego orędzia, które jest dla Kościoła po wszystkie czasy źródłem życia. $Z$ tego powodu apostołowie zatroszczyli się o to, by ustanowić swoich następców ${ }^{175}$. Zatem kolegium apostolskiemu $\mathrm{z}$ Piotrem na czele odpowiada dziś kolegium $\mathrm{z}$ biskupem Rzymu jako przewodniczącym. Biskupi są oficjalnymi przedstawicielami Chrystusa. Vaticanum II uczy, że:

W osobach biskupów, których pomocnikami są kapłani, obecny jest wśród wiernych Pan Jezus Chrystus, Kapłan Najwyższy. Siedząc bowiem po prawicy Ojca, przebywa równocześnie w zgromadzeniu swoich biskupów i za pośrednictwem przede wszystkim ich zaszczytnej służby, słowo Boże głosi wszystkim narodom, a wiernym udziela sakramentów wiary ${ }^{176}$.

Funkcja biskupów polega więc na zastępowaniu widzialnej obecności Chrystusa. W tym znaczeniu można mówić o „sakramentach w postaci osób”: biskupi są znakami, poprzez które działa sam Chrystus. Bez względu na sposób ich wyznaczania, który ulegał zmianom na przestrzeni historii, nie są oni w żadnym wypadku delegatami społeczności religijnej, ale pełnią rolę narzędzi Chrystusa. Zatem w Kościele mamy ustrój hierarchiczny, a nie demokratyczny: to Chrystus przez swoją łaskę uświęca biskupów przy ich wolnym współdziałaniu.

Biskupi spełniają potrójną funkcję i dlatego wyposażeni są w potrójną władzę:

- władzę nauczania, nazywaną Urzędem Nauczycielskim Kościoła,

- władzę kapłańską, dotyczącą składania ofiary i udzielania sakramentów, zwłaszcza sakramentu święceń,

175 Por. KK 20.

176 KK 21; por. DK 5. 
- władzę jurysdykcyjną, dotyczącą rządów wewnętrznych Kościoła.

Urząd Nauczycielski Kościoła istnieje po to, aby zachować w stanie nienaruszonym depozyt Objawienia, interpretować go i przekazywać. Kościól, ujmowany w całości, jest nieomylny, co oznacza, że nigdy nie przyjmie nauki sprzecznej z Objawieniem. Jednym z zasadniczych środków zachowania tej nieomylności jest Urząd Nauczycielski Kościoła, czyli kolegium biskupie z papieżem na czele.

Z kolei celem władzy kapłańskiej jest uświęcanie wiernych, co realizuje się przez sprawowanie sakramentów. Biskupi otrzymują tę władzę - pełnię kapłaństwa - poprzez święcenia. Mogą ją przekazywać albo w całości - wyświęcając biskupów, albo częściowo - udzielając święceń kapłańskich na stopniu prezbiteratu i diakonatu. Przekazanie pełnej władzy kapłańskiej może się dokonać prawnie za zgodą papieża, ale nawet wówczas, gdy biskupi czynią to wbrew niemu, jest ono ważne. Dlatego Kościoły odłączone, nieposiadające więzi ze Stolicą Apostolską, mogą w swym obrębie przekazywać godność biskupa i święcenia kapłańskie. Pod względem samej władzy kapłańskiej papież nie stoi wyżej od biskupów.

Trzecią funkcją biskupów jest sprawowanie rządów w Kościele, czyli władza jurysdykcji. Dotyczy ona relacji między katolikami, a jej celem jest zapewnienie właściwej organizacji Kościoła, czyli umożliwienie sprawnego działania ludu Bożego realizującego swoją misję w historii.

\section{B. PAPIEŻ A KOLEGIUM BISKUPÓW}

Biskupi w swej władzy są uzależnieni od papieża. Szczególny sens miejsca i pozycji biskupa Rzymu, jak zaznacza Lumen gentium, zamyka się w słowie ,jedność”:

Żeby zaś episkopat był jeden i niepodzielny, [Chrystus] postawił nad innymi Apostołami świętego Piotra i w nim ustanowił trwałą i widzialną zasadę i fundament jedności i wspólnoty ${ }^{177}$.

$Z$ powyższego tekstu wynika, że papież gwarantuje i urzeczywistnia widzialną wspólnotę. Dzięki niemu Kościół na zewnątrz, tu na ziemi, realizuje to, czym jest w sposób wewnętrzny i niewidzialny: tajemnicę wspólnoty i jedności. Tak koresponduje ze sobą i harmonizuje w Kościele to, co zewnętrzne i to, co wewnętrzne, res et sacramentum. Jak Kościół ma jedną głowę niewidzialną - Chrystusa, tak też posiada jedną głowę widzialną - papieża, nie tylko swego najwyższego przywódcę, lecz osobę, w której i poprzez którą instytucja ukazuje i urzeczywistnia fakt bycia sakramentem jedności. Tylko do papieża można odnosić słowa św. Ambrożego: Ubi Petrus, ibi Ecclesia („gdzie Piotr, tam Kościół”).

177 KK 18. 
Jednym z najczęściej dyskutowanych zagadnień doktrynalnych na ostatnim Soborze był problem relacji pomiędzy papieżem a kolegium biskupów. Jedność między nimi tak tłumaczy Vaticanum II:

Już starożytna zasada, na mocy której biskupi ustanowieni w całym świecie łączyli się ze sobą nawzajem i z Biskupem Rzymskim węzłem jedności, miłości i pokoju, a także zwołane ich synody, dla wspólnego rozstrzygania wszelkich ważniejszych spraw decyzją opartą na zdaniu wielu uczestników, wskazują kolegialny charakter i naturę episkopatu; jasno też potwierdzają tę kolegialność Sobory powszechne odbyte w ciągu wieków. Wskazuje na nią zresztą już sama, od czasów starożytnych stosowana praktyka zwoływania większej liczby biskupów, aby uczestniczyli w wyniesieniu nowego elekta na urząd najwyższego kapłaństwa. Członkiem kolegium biskupiego zostaje się na mocy sakramentalnej konsekracji i hierarchicznej wspólnoty z Głową Kolegium oraz jego członkami ${ }^{178}$.

Konsekwencją jedności i kolegialności biskupów jest fakt posiada przez to jedno ciało misji kierowania Kościołem. O ile każdy biskup jest pasterzem swojej diecezji, o tyle jako następca apostoła odpowiada za misję apostolską całego Kościoła.

Miejsce szczególne w kolegium biskupów zajmuje papież: „Biskup Rzymski, jako następca Piotra, jest trwałym i widzialnym źródłem i fundamentem jedności zarówno biskupów, jak i rzesz wiernych" ${ }^{179}$. Nie chodzi tu o przeciwstawianie papieża biskupom, lecz o wydobycie dwóch wzajemnie się dopełniających elementów struktury Kościoła. Po pierwsze, kolegium biskupów nie może istnieć ani wypełniać swojej misji, jeśli nie posiada wspólnoty ze swoją głową - papieżem. Papież natomiast nie może rządzić Kościołem sam jeden, bez porozumienia z biskupami. W tym sensie kolegium biskupów nie jest jedynie radą dla papieża. Sobór wyraźnie pozostawia miejsce na inicjatywę ze strony biskupów w kierowaniu Kościołem ${ }^{180}$.

Biskupi są członkami kolegium, któremu wraz z papieżem powierzona została odpowiedzialność za cały Kościół, ale jednocześnie osobiście odpowiadają za część ludu Bożego poddaną ich władzy. Z podwójności funkcji wynika podwójny aspekt ich władzy: w swojej diecezji każdy biskup posiada władzę zwyczajną i bezpośrednią, nie będąc jedynie delegatem papieża, ale przedstawicielem Chrystusa w powierzonym mu Kościele partykularnym, jednakże nie może wypełniać swej władzy niezależnie od całego kolegium, ponieważ sam jest jego częścią. Natomiast jako członek kolegium każdy biskup solidarnie ponosi odpowiedzialność za cały Kościół ${ }^{181}$. Czyni to poprzez udział w pracach soborów, synodów i konferencji

178 KK 22.

179 KK 23.

180 Por. KK 22, 23.

181 Por. KK 50. 
episkopatu ${ }^{182}$. Troska biskupa o cały Kościół przejawia się również w jego pomocy innym diecezjom poprzez dzielenie się np. kapłanami czy dobrami materialnymi.

Podsumowując omawianie znamion Kościoła, można podkreślić zasadnicze kwestie towarzyszące refleksji eklezjologicznej w tym zakresie.

Starając się udokumentować, że „ten jedyny Kościół Chrystusowy, który wyznajemy w Symbolu wiary jako jeden, święty, katolicki i apostolski”, ,trwa w Kościele katolickim, rządzonym przez następcę Piotra oraz biskupów pozostających z nim we wspólnocie (communio)”, pamiętamy, że i „poza jego organizmem znajdują się liczne pierwiastki uświęcenia i prawdy". Dlatego

słuszną i zbawienną rzeczą jest poznać Chrystusowe bogactwa i cnotliwe postępowanie w życiu drugich, którzy dają świadectwo Chrystusowi, czasem aż do przelania krwi ${ }^{183}$.

A także przyjąć, że same ich „Kościoły i odłączone wspólnoty, choć w naszym przekonaniu podlegają brakom, wcale nie są pozbawione znaczenia i wagi w tajemnicy zbawienia”. Bowiem

Duch Święty nie wzbrania się... posługiwać nimi jako środkami zbawienia, których moc pochodzi z samej pełni łaski i prawdy powierzonej Kościołowi katolickiemu ${ }^{184}$.

Sobór Watykański II zaznacza też z całą stanowczością:

Mimo że Kościół katolicki ubogacony został wszelką prawdą objawioną przez Boga i wszelkimi środkami łaski, to jednak jego członkowie nie żyją pełnią gorliwości w oparciu o nie, jakby to należało, tak, że oblicze Kościoła za mało świeci braciom od nas odłączonym i całemu światu, a wzrost Królestwa Bożego ulega opóźnieniu. Wobec tego wszyscy katolicy powinni dążyć do chrześcijańskiej doskonałości, a każdy - zależnie od swego stanu - ma dokładać starań, by Kościół nosząc w swym ciele Jezusowe uniżenie i umartwienie, oczyszczał się z dnia na dzień i odnawiał, aż stanie się dla Chrystusa pełen chwały, bez skazy i zmarszczki ${ }^{185}$.

Same znamiona ofiarowane przez Chrystusa Kościołowi katolickiemu są mu jednocześnie zadane: „aby się tak wydoskonalili w jedności, aby świat uwierzył i poznał" (por. J 17, 21.23).

\footnotetext{
${ }_{182}$ Por. B. Milne, Poznaj prawdę. Kompendium teologii chrześcijańskiej, Katowice 1992, s. 193.

183 DE 4.

184 DE 3.

185 DE 4.
} 
1. Jedność - zagwarantowana przez hierarchiczny ustrój z jednym następcą Piotra, jedno nieomylne Magisterium Kościoła nauczające wiary i moralności oraz tożsamość sprawowanych z mandatu kolegium biskupów sakramentów wymaga stałego życia i wzrostu w miłości wzajemnej w stosunku do wszystkich, których łączy w Chrystusowym Kościele jeden chrzest.

2. Świętość - udostępniona przez sprawowane sakramenty, wykładaną naukę Biblii komentowaną życiem świętych, nieustanną publiczną modlitwę w świadomej łączności z Kościołem chwalebnym i cierpiącym, ustanowione i chronione przez Kościół formy życia konsekrowanego i otwarcie na nowe tchnienia Ducha Świętego, ochronę świętości i trwałości małżeństwa i rodziny - domaga się stałej realizacji w życiu poszczególnych członków i wszystkich wspólnot tworzących lud Boży.

3. Katolickość - wyrażająca się w obejmowaniu ludzi różnych kultur, narodów, stanów, sposobów życia i w pragnieniu przybierającym konkretne i zorganizowane kształty misji docierania do wszystkich ludzi - domaga się coraz pełniejszego i oryginalnego wkładu każdego człowieka bądź kultury w budowę pełni Chrystusa.

4. Apostolskość - chroniona ciągłością przekazu apostolskiego posłannictwa i nauki w nieprzerwanie trwających wspólnotach - wymaga stałego wzrostu w miłości, wierności, posłuszeństwie wobec następców apostołów i tych, którzy mają zlecony przez nich udział w ich posługiwaniu oraz wobec głoszonej przez nich Ewangelii.

Wszyscy, którzy jesteśmy synami Bożymi i stanowimy jedną rodzinę, w Chrystusie, gdy łączymy się ze sobą we wzajemnej miłości i w jednej chwale Trójcy Przenajświętszej, odpowiadamy najgłębszemu powołaniu Kościoła” (KK 51), „który w osobie Najświętszej Maryi Panny już osiąga doskonałość ${ }^{186}$.

\section{F. Maryja Boża Rodzicielka figurą Kościoła}

Teologia fundamentalna, która bada tzw. zewnętrzne znaki wiarygodności wiary, Objawienia i Kościoła łącznie z ich historycznymi założeniami i faktami, stwierdza po prostu, że historia Jezusa jest w całości „obramowana” ziemskim życiem Maryi. Ona bowiem poczęła Go jako matka, stała przy Jego krzyżu, była świadkiem Jego wstąpienia do nieba oraz znajdowała się pośrodku apostolskiego Kościoła przyjmującego Ducha Świętego i rozpoczynającego swoją misję do wszystkich ludów wszystkich czasów.

186 KK 65. 
W kolejnych fazach swojej historii Kościół podejmował problematykę maryjnąak by lepiej rozpoznać istotę swojej wiary obejmującej posłanie Jezusa Chrystusa. W swoim kazaniu na soborze w Efezie (431) św. Cyryl Aleksandryjski, nazywając Maryję „Berłem prawdziwej wiary”, uznał, że rozumie się przez nią, kim jest Jezus Chrystus ${ }^{187}$. Papież Leon Wielki w liście do Flawiana, ujmując doktrynę chrześcijańską jako wyznanie wiary w Boga - wszechmogącego Ojca, w Jezusa Chrystusa, Jego jednorodzonego Syna, naszego Pana, który przez Ducha Świętego narodził się z Maryi Dziewicy - dodał: „Dzięki tym trzem zdaniom są unicestwione machinacje prawie wszystkich heretyków". ${ }^{188}$ Co zostało wypowiedziane negatywnie w sformułowaniu ,przezwyciężenia herezji”, pozwoliło się pozytywnie wyrazić w dokumentach Vaticanum II: „Maryja, która wkroczywszy głęboko w dzieje zbawienia, łączy w sobie w pewien sposób i odzwierciedla najważniejsze treści wiary [...]"189.

Postać Maryi związana jest ściśle z początkami Kościoła, z jego posłaniem $\mathrm{w}$ historii i z ostatecznym celem jego ziemskiego pielgrzymowania. Niniejsze ujęcie skoncentruje się na przypomnieniu istotnych akcentów mariologii Soboru Watykańskiego II, którego nauczanie łączy mariologię z eklezjologią.

\section{Wzajemne odniesienie Maryi i Kościoła}

Nauka Nowego Testamentu o Najświętszej Maryi wykracza poza wskazanie na więzi łączące ją z Synem i Jego dziełem zbawczym. Jej działanie dotyczy uczniów Syna, którzy stanowili zalążek tworzącej się wspólnoty Kościoła, co uwidacznia się na początku publicznej działalności Jezusa w Kanie (por. J 2, 1-11) czy przy wypełnieniu działania zbawczego pod krzyżem (por. J 19, 25-27). Maryja jest czynnym świadkiem objawienia się Kościoła w Zielone Święta (por. Dz 1, 14).

Treść myśli z jej pieśni (por. Łk 1, 46-55), która jest w pewnej mierze zaczątkiem mariologii, wskazuje, że Maryja objawia jedyną w swoim rodzaju indywidualną cechę przekraczającą horyzont Starego Testamentu, a wyrażoną zwrotami: „mój Zbawiciel”, „wielkie rzeczy uczynił mi Wszechmocny” czy „odtąd błogosławioną zwać mnie będą wszystkie narody”.,Jako obiekt Bożego działania Maryja reprezentuje Izraela w nowy sposób; Ona przedstawia nowy lud Boży, który dzięki Jej wsparciu zaczyna powstawać” ${ }^{190}$.

187 Cyt. za: M. Hauke, Maria - Urbild und Fülle des Katholischen, [w:] W. Brandmüller (red.), Das eigentlich Katholische, Aachen 1997, s. 205.

188 Por. tamże, s. 205.

189 KK 65.

190 W. Kirschläger, „Magnificat I. Exegese“, [w:] R. Bäumer, L. Scheffczyk (red.), Marienlexikon, t. 4, Regensburg 1992, s. 236. 
Związek pomiędzy Maryją a Kościołem pogłębia wizja „wielkiego znaku”, niewiasty ubranej $\mathrm{w}$ słońce $\mathrm{z}$ koroną $\mathrm{z}$ dwunastu gwiazd na głowie $\mathrm{z}$ dwunastego rozdziału Apokalipsy. Przedstawiono tam w ogólności los ludu Bożego, w którym wypełnia się obietnica Protoewangelii przez zwycięstwo potomstwa niewiasty nad wężem (por. Rdz 3, 15). Obraz ukazanej tam niewiasty ogniskuje w sobie w śmiałej syntezie starotestamentalny lud Boży jako małżonki Jahwe oraz Kościół jako nowy Izrael. Równocześnie wskazuje na indywidualne rysy ziemskiej Matki Mesjasza - Emmanuela, a przez to jest otwarty na maryjno-eklezjologiczną interpretację ${ }^{191}$.

Matka Mesjasza jest znakiem i prawzorem dla bytu Kościoła w odniesieniu do duchowego macierzyństwa jak i znaku niepokonalności pomimo prześladowań... Gdzie Kościół widziany jest w jego ostatecznym i najgłębszym określeniu, ma w swoim obrazie apokaliptycznej niewiasty maryjne cechy ${ }^{192}$.

Ojcowie Kościoła podjęli biblijna naukę o wzajemnym odniesieniu Maryi i Kościoła, ubogacając ją wyrazistą teologią. Św. Ambroży nazwie ją typus Ecclesiae, „prawzorem Kościoła”, w porządku wiary, nadziei i miłości ${ }^{193}$. Św. Cyryl Aleksandryjski w swoim kazaniu na soborze w Efezie ośmiela się wprost utożsamić Maryję z Kościołem, kiedy mówi:

przez Ciebie jest udzielany chrzest wszystkim wierzącym [...] przez Ciebie prowadzone są wszystkie ludy do nawrócenia [...]. Chcemy czcić zawsze dziewiczą Maryję, a więc święty Kościól,Jej Syna i nieskalanego Oblubieńca. Jemu niech będzie chwała po wszystkie wieki.

Cytując te słowa, współczesny teolog doda komentarz: „Maryja jest tu dla kaznodziei ponad wszystko żywym i konkretnym uosobieniem Kościoła[...]. Maryja, konkretny, uniwersalny Kościół"194.

Owo szczególne wzajemne odniesienie i powiązanie jest widoczne w relacji między dziewictwem i macierzyństwem Maryi do Kościoła, co mocno zostało zaakcentowane przez Vaticanum II:

191 Por. A. Jankowski, Apokalipsa świętego Jana, [w:] A. Jankowski, K. Romaniuk, L. Stachowiak, Komentarz praktyczny do Nowego Testamentu, cz. 2, Poznań-Warszawa 1975, s. 1171; M. Hauke, Maria - Urbild und Fülle des Katholischen, art. cyt., 209.

192 A. Ziegenaus, „Apokalyptische Frau II. Dogmatik“, [w:] R. Bäumer, L. Scheffczyk (red.), Marienlexikon, t. 1, Regensburg 1988, s. 191; B. Forte, Maria, Mutter und Schwester des Glaubens, Zürich 1990, s. 94-97.

193 Jego naukę cytuje KK 63.

194 A. Müller, Ecclesia-Maria. Die Einheit Marias und der Kirche (Paradosis 5), Freiburg/ Schweiz 1955, s. 156n. 
W tajemnicy bowiem Kościoła, który sam także słusznie nazywany jest matką i dziewicąak, Błogosławiona Dziewica Maryja przodowała najdoskonalej i osobliwie, stając się wzorem dziewicy i zarazem matki. Wierząc bowiem i będąc posłuszną, zrodziła na ziemi samego Syna Boga Ojca, i to nie znając męża, Duchem Świętym zacieniona, niby nowa Ewa, która nie dawnemu wężowi, lecz wysłannikowi Bożemu dała wiarę nie skażoną żadnym wątpieniem. Zrodziła zaś Syna, którego Bóg ustanowił pierworodnym między wielu braćmi (Rz 8, 29), to znaczy między wiernymi, w których zrodzeniu współdziałała swą miłością macierzyńską ${ }^{195}$.

W nauce o Kościele zarysowana została cała mariologia, jak to określa J. Ratzinger:

Dziewica Kościół, Matka Kościoła, Kościół niepokalany, Kościół wniebowzięty - wszystko, co później stanie się mariologią, zostało najpierw pomyślane jako eklezjologia ${ }^{196}$.

\section{2. „Maryjna" i „Piotrowa” zasada Kościoła197}

W Piśmie Świętym i Tradycji przyjmujący zbawienie Kościół przedstawiany jest w obrazach znamionujących cechy kobiety: dziewicy, oblubienicy i matki. Ta niewieścio-macierzyńska zasada, określająca Kościół od wewnątrz, odróżnia się od, związanej z apostołami, zasady ojcowsko-urzędowej i autorytatywnej. To rozróżnienie uwidacznia się wyraźnie w nauce apostolskiej. Męsko-ojcowska zasada występuje wyraźnie w słowach apostoła: „Przez Ewangelię stałem się dla was ojcem (zrodziłem) was w Chrystusie Jezusie” (1 Kor 4, 15). Niewieścio-macierzyńską zasadę św. Paweł podkreśla następująco: „Poślubiłem was przecież jednemu mężowi, by was przedstawić Chrystusowi jako czystą dziewicę" (2 Kor 11, 2).

$\mathrm{Na}$ tę typologię naprowadza tė̇ Jan Paweł II w Mulieris dignitatem ${ }^{198}$, rozró $\dot{z}^{-}$ niając w Kościele profil „maryjny” i profil „apostolsko-piotrowy”, w czym nawiązuje do inspirujących myśli H. U. von Balthasara:

195 KK 63.

196 Erwägungen zur Stellung von Mariologie und Marienfrömmigkeit im Ganzen von Glaube und Theologie, [w:] J. Ratzinger, H. U. von Balthasar, Maria-Kirche im Ursprung, Freiburg i. Br. 1980, s. 27.

197 Por. L. Scheffczyk, Petrus und Maria: Hindernis oder Helfer auf dem Weg der Einheit, [w:] „Catholica“ 34 (1980), s. 62-65; H. U. von Balthasar, Der antirömische Affekt, Freiburg i. Br. 1974, s. 153-187; tenże, „Frauenpriestertum?“, [w:] tenże, Neue Klarstellung, Einsiedeln 1979, s. 109-155; M. Hauke, Maria - Urbild und Fülle des Katholischen, art. cyt., s. 205-228.

198 Por. Mulieris dignitatem, 27. 
Ów profil maryjny jest dla Kościoła równie, a może nawet bardziej istotny i charakterystyczny niż głęboko z nim związany profil apostolski i Piotrowy (...) Maryjny wymiar Kościoła znajduje się przed wymiarem Piotrowym, choć jest z nim ściśle związany i wobec niego komplementarny. Niepokalana poprzedza wszystkich, a więc także samego Piotra i apostołów. Dzieje się tak nie tylko dlatego, że Piotr i apostołowie, jak cały rodzaj ludzki zrodzony w stanie grzechu, wchodzą w skład Ecclesia sancta ex peccatoribus, ale także dlatego, że jedynym celem ich potrójnego munus jest budowanie Kościoła według tego ideału świętości, którego modelem i pierwowzorem jest Maryja. Jak słusznie zauważył jeden ze współczesnych teologów, Maryja jest „Królową apostołów”, ale nie rości sobie prawa do władzy apostolskiej. Jej władza jest inna i większa ${ }^{199}$.

Zasada „apostolsko-piotrowa” odnosi się do hierarchii opartej na święceniach sakramentalnych, w których Chrystus jako głowa Kościoła działa w swojej człowieczej konkretności. Zaś zasada „maryjna” oznacza doskonale odwzorowaną w Maryi postawę chrześcijanina, która znajduje swój wyraz w powszechnym kapłaństwie wszystkich ochrzczonych.

Należy tutaj dodać, że to rozróżnienie i zarazem pełne życia zbalansowanie męsko-ojcowskiej zasady z ucieleśnioną w Maryi zasadą niewieścio-macierzyńską ma znaczenie nie tylko teologiczne. Głosząc je, Kościół katolicki okazuje się w dzisiejszym świecie jako jedyna kulturowa siła, która przeciwstawia się nieładowi niszczącej niwelacji płci i powrotowi antyludzkiego pogańskiego mitu androgyna ${ }^{200}$.

Potwierdzenie zasady „maryjnej” teologia widzi w znamionach, które tworzą personalny charakter Maryi: w postawie wiary pełnej oddania, w całkowitej dyspozycyjności dla Zbawiciela, w służebnej postawie wobec Pana i Sprawcy zbawienia, a także wobec zbawczego przekazu w Kościele.

\section{Maryja jako osobowe świadectwo pełnej świętości Kościoła}

Przy proklamowaniu prawdy o świętości Kościoła powstaje pytanie, czy chodzi tu o wymarzony, a w konkrecie życia nierzeczywisty ideał, czy też o możliwość jego osiągnięcia przez każdego wierzącego. Kościół jest świadom otrzymanych od swego Założyciela darów świętości i uświęcania ${ }^{201}$.

199 Neue Klarstellungen, dz. cyt., s. 181; por. Jan Paweł II, Przemówienie do Kolegium Kardynalskiego I cztonków Kurii Rzymskiej (27. 12. 1987) [w:] „L'Osservatore Romano”, (wyd. polskie), (1988), nr 1 (98), dodatek do rocznika 1987.

200 Por. L. Scheffczyk, Strukturen katholischen Ganzheitsschau, [w:] W. Brandmüller, Das eigentlich Katholische, Aachen 1997, s. 31.

201 Które jako takie nie są wypaczone i niosą obiektywną świętość, np. wiara, życie sakramentalne, struktura hierarchiczna, por. Y. Congar, Die Wesenseigenschaften der Kirche, 
W Maryi Kościół odnajduje jedyną ludzką osobę, w której zbawienie dokonane przez Jezusa Chrystusa wypełniło się doskonale: przez ustrzeżenie od grzechu pierworodnego oraz całkowitą wolność od jakiegokolwiek grzechu osobistego. W Niej Kościół widzi nową Ewę, w której odnowił się i wypełnił rajski początek. Kościół może zaświadczyć przez wskazanie na Maryję, że świętość nie jest jakimś odległym celem czy też ideą, ale realnym owocem współdziałania człowieka z łaską Bożą, dostępnym dla każdego wierzącego. W jej doskonałej świętości Kościół już osiągnął pełnię świętości i to całkiem konkretnie. Maryja i Kościół odnajdują się w perychorezie, we wzajemnym przenikaniu świętości ${ }^{202}$.

Vaticanum II przekazuje tę naukę, zwracając przy tym uwagę na trzy aspekty związane ze świętością Maryi. Jest to nade wszystko wzorcowa wiara, która utwierdzała się u niej i rosła nieprzerwanie przez wszystkie fazy jej ziemskiego życia. ${ }^{203}$ Wpatrzony w ten przykład Kościół, poprzez wieki uczy swoje dzieci na przykładzie Maryi całkowitego przylgnięcia do Boga przez coraz dojrzalsze przyjmowanie Objawienia i ukrytych w nim skarbów zbawienia ${ }^{204}$. $Z$ wiarą Maryi związane jest ściśle jej postuszeństwo. Cecha ta bowiem najbardziej upodabnia do samego Jezusa Chrystusa podejmującego zbawienie w posłuszeństwie aż do śmierci. Wzór Maryi poddanej słowu Bożemu stanowi przynaglające wezwanie, aby Kościół w całym swoim życiu i działaniu kierował się wyłącznie wolą Bożą ${ }^{205}$. Owocem świętości Kościoła na wzór Maryi jest macierzyńska miłość, która „powinna ożywiać wszystkich, którzy współdziałają w apostolskim posłannictwie Kościoła dla odradzania ludzi"206.

\section{Maryja jako znak nadziei}

Maryja nie przestała być członkiem Kościoła w momencie jej cielesnego wyniesienia do chwały niebieskiej. Właśnie to uwielbienie w chwale Trójcy Świętej wskazuje na pełną wzorcowość jej odniesienia do Kościoła, dla którego jest osobowym znakiem doskonałego wypełnienia się całego dzieła zbawienia.

[w:] Mysterium Salutis, t. IV/1: Das Heilsgeschehen in der Gemeinde, Einsiedeln-Zürich-Köln 1972, s. 468-471.

202 Por. M. J. Scheeben, Handbuch der Dogmatik, V, 2, [w:] Gesamte Schriften, t. VI, 2), Freiburg i. Br. ${ }^{2} 1954$, nr 1819 , s. 488.

203 VIII rozdział Lumen gentium w odniesieniu do Maryi wiarę wspomina jedenaście razy, por. B. Przybylski, Matka Boża w Kościele, [w:] H. Bogacki (red.), Kościót w świetle Soboru, Poznań 1967, s. 320.

204 Por. KK 65.

205 Por. KK 65.

206 KK 65. 
Staje się przez to znakiem niezawodnej nadziei i pocieszeniem dla całej "społeczności pielgrzymującego Ludu Bożego:

Tymczasem zaś Matka Jezusowa, jak w niebie doznaje już chwały co do ciała i duszy, będąc obrazem i początkiem Kościoła mającego osiągnąć pełnię w przyszłym wieku, tak tu na ziemi, póki nie nadejdzie dzień Pański (por. 2 P 3, 10), przyświeca Ludowi Bożemu pielgrzymującemu jako znak pewnej nadziei i pociechy ${ }^{207}$.

Nadzieja ta ma także charakter wspólnotowy i dotyczy nie tylko Kościoła, ale całego rodzaju ludzkiego. Dlatego Vaticanum II usilnie zachęca wiernych, aby wytrwale błagali Matkę Boga i Matkę ludzi, Maryję, aby ta, „która modlitwami swymi wspierała początki Kościoła, także i teraz w niebie, wywyższona ponad wszystkich świętych i aniołów, we Wspólnocie wszystkich Świętych wstawiała się u Syna swego, dopóki wszystkie rodziny ludów, zarówno tych, którzy noszą zaszczytne imię chrześcijańskie, jak i tych, którzy nie znają jeszcze swego Zbawiciela, nie zespolą się szczęśliwie w pokoju i zgodzie w jeden lud Boży na chwałę Przenajświętszej i nierozdzielnej Trójcy"208.

\section{Maryja Matką Kościoła}

Tytuł Maryi jako „Matki Kościoła” nie występuje ani w Piśmie Świętym, ani w patrystycznej tradycji kościelnej. Pojawił się po raz pierwszy w XII w. ${ }^{209}$ Posługiwał się nim papież Leon XIII, a także kilkakrotnie, choć bez teologicznego uzasadnienia, Jan XXIII.

Podczas obrad Vaticanum II, 21 listopada 1964 r., papież Paweł VI w uroczysty sposób proklamował Maryję Matką Kościoła: „Ku chwale Najświętszej Maryi Panny oraz ku naszej radości ogłaszamy Najświętszą Maryję Pannę Matką Kościoła, czyli całego ludu chrześcijańskiego, zarówno wiernych, jak pasterzy, którzy wszyscy zwą ją swoją Matką najmilszą"210.

Ten papieski akt ma wyjątkową rangę, gdyż był dokonany w obecności soboru i wiązał się z uroczystym przyjęciem w tym dniu Konstytucji dogmatycznej o Kościele Lumen gentium. Nie posiada on charakteru dogmatycznego, ale w formie kultowo-duszpasterskiej, jak to zaznaczył sam Paweł VI, „określa ze

\footnotetext{
207 KK 68.

208 KK 69.

209 Por. B. Przybylski, Matka Boża w Kościele, art. cyt., s. 324.

210 AAS 56 (1964), s. 1015.
} 
wspaniałą zwięzłością wyjątkowe miejsce Matki Bożej w Kościele, wedle nauki obecnego soboru"211.

VIII rozdział Lumen gentium wspomina kilkakrotnie - bez użycia tego tytułu - o macierzyńskiej roli Maryi w stosunku do Kościoła jako wspólnoty wiernych. Macierzyństwo to jest nade wszystko wzorem doskonałego ucznia Chrystusowego. Maryja wzywa - jak każda matka swe dzieci - „do naśladowania w wierze, w chętnej uległości wobec każdej łaski otrzymywanej z nieba, a wreszcie w kształtowaniu własnego życia całkowicie według Chrystusowych przykazań i wymogów miłości”212.

Celem ogłoszenia tytułu Matki Kościoła było właściwe dowartościowanie mariologii w teologii i wzmożenie jej kultu w całym Kościele ${ }^{213}$, aby przez rozważanie niezgłębionych bogactw tajemnicy Maryi nie tylko otoczyć ją jeszcze większą chwałą, ale złączyć wiernych prawdą posiadania wspólnej Matki, a przez to umocnić w nich wiarę i miłość ku bliźnim i wzmóc gorliwość poznawania dzieła jej Syna, Jezusa Chrystusa. ${ }^{2}$

\section{Cześć Najświętszej Maryi w Kościele}

Cześć Najświętszej Maryi trwa w Kościele od samych jego początków. Oparta jest na wyjątkowej godności („Najświętszej Matki Boga, która uczestniczyła w tajemnicy Chrystusa”214) i wynika nie tylko ze słuszności, ale obowiązku „ludzi odkupionych wobec Bożej Rodzicielki, Matki Chrystusa i Matki ludzi, zwłaszcza wiernych"215. Cześć dla Maryi, pod obronę której wierni uciekają się we wszystkich swoich sprawach, ma być w Kościele świadectwem podziwu i wysławiania wspaniałego owocu odkupienia i oglądania w przeczystym obrazie tego, „czym cały pragnie i spodziewa się być”216.

Cześć Maryi w Kościele, zwłaszcza w jej wymiarze kultycznym, ma w swoim charakterze praktycznym wynikać nade wszystko z treści nauki maryjnej przedłożonej przez Kościól, ze szczególnym podkreśleniem jej korzeni chrystologicznych, jak też kierować się duchem całej odnowy liturgicznej Kościoła podjętej

\footnotetext{
211 Tamże, s. 1015.

212 Tamże, s. 1015.

213 Michael Schmaus (+ 1993), wskazywał, że w mariologii zbiegają się wszystkie teologiczne ścieżki (Linien), „chrystologiczne, eklezjologiczne, antropologiczne i eschatologiczne”. W mariologii uwydatniają się też w szczególnej jasności i wyrazistości (Schärfe) pytania o metodę teologii. Teologiem systematykiem może być tylko dobry mariolog, por. tenże, Katholische Dogmatik V: Mariologie, ${ }^{2}$ München 1961, s. 8.

${ }^{214}$ KK 66.

215 KK 54.

216 KL 103.
} 
na Vaticanum II. W swoim końcowym zamierzeniu - jak naucza Paweł VI ma być pomocą, „która z natury swej prowadzi ludzi do Chrystusa i łączy ich z Przedwiecznym Ojcem w niebiesiech więzią miłości zadzierzgniętą w Duchu Świętym". Ma się to dokonywać także przez podkreślenie, uwypuklenie i pogłębianie więzi Maryi z wiernym ludem².

1 AAS 56 (1964), s. 1016.

2 M. Hauke, Das marianische Prinzip, [w:] tenże, Klarstellungen, Einsiedeln 1978, s. 227. 